\title{
The Fixed Propeller-Like Conformation of Tetraphenylethylene that Reveals Aggregation-Induced Emission Effect, Chiral Recognition and Enhanced Optical Property
}

\author{
Jia-Bin Xiong,,$^{\dagger}$ Hai-Tao Feng,,$^{\dagger}$ Jian-Ping Sun, ${ }^{\dagger}$ Wen-Zhao Xie,,$^{\dagger}$ Dong Yang, ${ }^{*}$ \\ Minghua Liu, ${ }^{*}$ and Yan-Song Zheng, ${ }^{*+}$ \\ ${ }^{\dagger}$ Key Laboratory of Material Chemistry for Energy Conversion and Storage, Ministry of Education, \\ School of Chemistry and Chemical Engineering, Huazhong University of Science and Technology, \\ Wuhan 430074, China.*zyansong@hotmail.com. \\ $\$$ Beijing National Laboratory for Molecular Science (BNLMS), CAS Key Laboratory of Colloid \\ Interface and Chemical Thermodynamics, Institute of Chemistry, Chinese Academy of Sciences, \\ Beijing 100190 , People's Republic of China.
}

\section{Table of Contents}

\begin{tabular}{|c|c|}
\hline Materials and Methods & $\mathrm{S} 2$ \\
\hline Synthesis of propeller-like TPE tetracycle $\mathbf{6}$ & S2-S6 \\
\hline${ }^{1} \mathrm{H} /{ }^{13} \mathrm{C}-\mathrm{NMR}$, IR and HRMS spectra of compound $\mathbf{2 , 3}, \mathbf{4}, \mathbf{6}, \mathrm{M}-\mathbf{6}$, and P-6 & S6-S23 \\
\hline Fig. S25. UV-vis spectra of compounds $\mathbf{2}, \mathbf{3}, \mathbf{4}$, and $\mathbf{6}$ in THF & S24 \\
\hline $\begin{array}{l}\text { Fig. S26. UV-vis spectra of compounds M-6, P-6, and racemic-6 in 90:10 } \\
\mathrm{H}_{2} \mathrm{O} / \mathrm{THF}\end{array}$ & S24 \\
\hline Fig. S27. Fluorescence spectra of 6, M-6 and P-6 in THF & S24 \\
\hline Fig. S28-S30. Change of fluorescence spectrum of $\mathbf{3}, \mathbf{4}$ and $\mathbf{6}$ with concentration & $\mathrm{S} 25-\mathrm{S} 26$ \\
\hline Fig. S31-S33. Normalized fluorescence spectra of $\mathbf{3}, \mathbf{4}$ and $\mathbf{6}$ & S26-S27 \\
\hline Fig. S34. Crystal structure and packing of $\mathbf{3}$ in crystal state & S28 \\
\hline Fig. S35. Change in ${ }^{1} \mathrm{H}$ NMR spectra of solution of $S-7$ and $\mathbf{3}$ in $\mathrm{CDCl}_{3}$ with time & S29 \\
\hline Fig. S36. CD spectra of the solution of enantiomers of chiral amine with $\mathbf{3}$ & S30 \\
\hline Fig. S37. CD spectra of the solution of enantiomers of chiral amine & S31 \\
\hline Fig. S38. CD spectra of the solution of enantiomers of chiral amine with 2 & S32 \\
\hline $\begin{array}{l}\text { Fig. S39. Change in CD spectra of the solution of } R-7, \mathbf{3} \text {, and HAc in 1,2- } \\
\text { dichloroethane with molar ratios of } R-7 \text { vs } 3 \text {. }\end{array}$ & S33 \\
\hline $\begin{array}{l}\text { Fig. S40. Change in fluorescence spectra of the solution of } R-7,3 \text {, and HAc in } \\
1,2 \text {-dichloroethane with molar ratios of } R-7 \text { vs } 3\end{array}$ & S33 \\
\hline $\begin{array}{l}\text { Fig. S41. Change in CD spectra of the solution of enantiomers of } 7,3 \text {, and HAc in } \\
1,2 \text {-dichloroethane with ee } \% \text { of } R-7\end{array}$ & S33 \\
\hline $\begin{array}{l}\text { Fig. S42. Change in CD spectra of } \mathbf{9}, \mathbf{3} \text {, and HAc in 1,2-dichloroethane with ee } \% \\
\text { of } R-\mathbf{9}\end{array}$ & S34 \\
\hline $\begin{array}{l}\text { Fig. S43. (A). Change in CD spectra of } \mathbf{1 2}, \mathbf{3} \text {, and HAc in acetonitrile with ee } \% \text { of } \\
R, R \mathbf{- 1 2}\end{array}$ & S34 \\
\hline $\begin{array}{l}\text { Fig. S44. Crystal structure (A) and packing with same helical chirality (B) of } 6 \text { in } \\
\text { crystal state }\end{array}$ & S35 \\
\hline $\begin{array}{l}\text { Fig. S45. Photos of powders of } 6(A), 4(B) \text { and } 3(C) \text { under a portable UV lamp } \\
\text { after ground and treated by methanol or dichloromethane }\end{array}$ & S36 \\
\hline
\end{tabular}




\section{Materials and Methods}

Materials: All reagents and solvents were chemical pure (CP) grade or analytical reagent (AR) grade and most of them were bought from China National Pharmaceutical Group Corporation, Aladdin (Shanghai) Bio-Chem Technology Co Ltd, and Meryer (Shanghai) Chemical Technology Co Ltd et al.. These reagents and solvents were used as received unless otherwise indicated.

Measurements: ${ }^{1} \mathrm{H}$ NMR and ${ }^{13} \mathrm{C}$ NMR spectra were measured on a Bruker AV 400 spectrometer at $298 \mathrm{~K}$ in $\mathrm{CDCl}_{3}$. Infrared spectra were recorded on Bruker EQUINAX55 spectrometer. Absorption spectra were recorded on a Hewlett Packard 8453 UV-Vis spectrophotometer. Mass spectrum was measured on an Ion Spec 4.7 Tesla FTMS instrument. The single crystal data of TPE-BODIPY was collected on Rigaku Saturn diffractometer with CCD area detector. All calculations were performed using the SHELXL97 and crystal structure crystallographic software packages. Fluorescent emission spectra were collected on a Shimadzu RF-5301 fluorophotometer at 298 K. Fluorescence lifetimes were recorded on Edinburgh instruments (FLS 920 spectrometers). The relative fluorescence quantum yields were measured using fluorescein $\left(\Phi_{\mathrm{f}}=0.89\right)$ in $0.10 \mathrm{M} \mathrm{NaOH}$ as standard. Absolute fluorescence quantum yields were recorded on Hamamatsu Absolute PL Quantum Yield Spectrometer C11347 with a calibrated integrating sphere system. Circular dichrorism (CD) spectra were recorded on a JASCO J-810 spectrometer. Circular polarized luminescence (CPL) spectra were measured on a JASCO CPL-200 spectrometer.

The resolution conditions of racemic 2 and racemic 3 by HPLC: For racemic 2: column, CHIRALPAK IE column; mobile phase, $\mathrm{CH}_{2} \mathrm{Cl}_{2} / \mathrm{CH}_{3} \mathrm{OH} / \mathrm{Et}_{3} \mathrm{~N}$ 80:20:0.1 (volume ratio). For racemic 3: column, CHIRALPAK IE column; mobile phase, $\mathrm{CH}_{2} \mathrm{Cl}_{2} / \mathrm{CH}_{3} \mathrm{OH}$ 80:20 (volume ratio).

\section{Synthesis of propeller-like TPE tetracycle 6.}

\section{Synthesis of 2.}

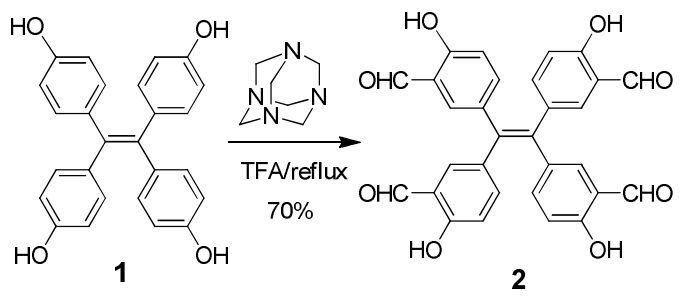

To a flask was added $1(1.0 \mathrm{~g}, 2.50 \mathrm{mmol})$, hexamethylenetetramine $(1.41 \mathrm{~g}, 10 \mathrm{mmol})$ and trifluoroacetic acid $(35 \mathrm{~mL})$. The solution was refluxed for $3 \mathrm{~h}$ and then cold water was added. 
After the mixture was stirred at room temperature for $3 \mathrm{~h}$, it was extracted with ethyl acetate. The combined organic phase was dried over anhydrous sodium sulfate, filtered and evaporated to dryness. The residue was subjected to column chromatography (silica gel, ethyl acetate : petroleum 1:4) to afford 2 as yellow solid (0.89 g, 70\%). $\mathrm{Mp}=289.2-290.5{ }^{\circ} \mathrm{C} ;{ }^{1} \mathrm{H}$ NMR (400 MHz, $\left.\mathrm{CDCl}_{3}\right) \delta 11.00(\mathrm{~s}, 4 \mathrm{H}), 9.66(\mathrm{~s}, 4 \mathrm{H}), 7.26-7.18(\mathrm{~m}, 8 \mathrm{H}), 6.81(\mathrm{~d}, J=9.4$ $\mathrm{Hz}, 4 \mathrm{H}) ;{ }^{13} \mathrm{C}$ NMR $\left(100 \mathrm{MHz}, \mathrm{CDCl}_{3}\right) \delta 196.1,160.7,139.7,137.7,136.0,134.2,120.5$, 117.9; IR (KBr) v 3459, 3054, 2854, 1653, 1481, 1281, 1215, 1157, 843, 746, $620 \mathrm{~cm}^{-1}$; $\mathrm{ES}^{+}$ HRMS m/z calcd for $\mathrm{C}_{30} \mathrm{H}_{20} \mathrm{O}_{8} 508.1158[\mathrm{M}]$, found $508.1199[\mathrm{M}]^{+}$.

\section{Synthesis of 3.}

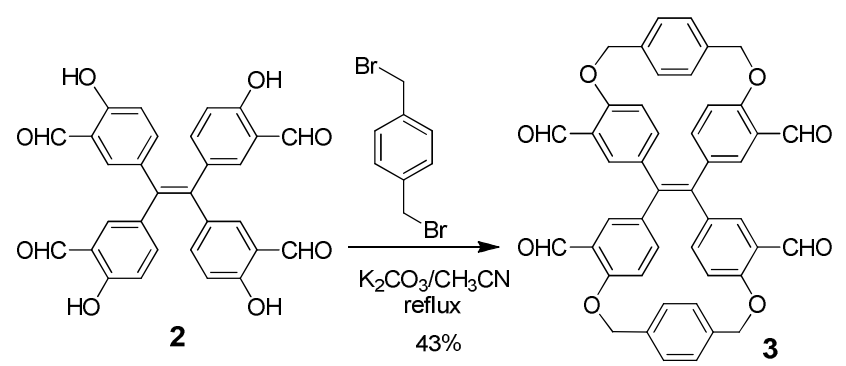

To a flask was added 2 (500 mg, $0.98 \mathrm{mmol})$, 1,4-bis(bromomethyl)benzene (570 mg, 2.16 $\mathrm{mmol})$, anhydrous potassium carbonate $(480 \mathrm{mg}, 3.48 \mathrm{mmol})$, and acetonitrile $(150 \mathrm{~mL})$. After the mixture was refluxed for about $6 \mathrm{~h}$, solvent was removed. Water and dichloromethane were added to give two phases solution. Organic phase was separated and water phase was extracted two times with dichloromethane. The combined organic phase was dried over anhydrous $\mathrm{Na}_{2} \mathrm{SO}_{4}$, filtered and evaporated to dryness. The residue was subjected to column chromatography (silica gel, ethyl acetate / dichloromethane 1:50) to afford $\mathbf{3}$ as a yellow solid (301 mg, 43\%). Mp = 293.7-294.8 ${ }^{\circ} \mathrm{C}:{ }^{1} \mathrm{H}$ NMR $\left(400 \mathrm{MHz}, \mathrm{DMSO}-\mathrm{d}_{6}\right) \delta 10.36$ (s, 4H) ,7.42 (d, $J=8.5 \mathrm{~Hz}, 4 \mathrm{H}), 7.19(\mathrm{~d}, J=8.5 \mathrm{~Hz}, 4 \mathrm{H}), 7.06(\mathrm{~d}, J=2.2 \mathrm{~Hz}, 4 \mathrm{H}), 6.69$ (dd, $J$ $=8.7 \mathrm{~Hz}, J=2.2 \mathrm{~Hz}, 4 \mathrm{H}), 6.58(\mathrm{~d}, J=8.7 \mathrm{~Hz}, 4 \mathrm{H}), 5.49(\mathrm{~d}, J=12.8 \mathrm{~Hz}, 4 \mathrm{H}), 5.36(\mathrm{~d}, J=$ $12.8 \mathrm{~Hz}, 4 \mathrm{H}) ;{ }^{13} \mathrm{C}$ NMR (100 MHz, DMSO-d $\left.{ }_{6}\right) \delta$ 189.6, 158.3, 140.9, 137.9, 136.1, 134.5, 132.2, 129.1, 127.5, 125.8, 116.9, 70.3; IR (KBr) v 3512, 3033, 2856, 1681, 1490, 1601, 1490 , $1394,1258,1215,1111,815,655 \mathrm{~cm}^{-1}$; $\mathrm{ES}^{+} \mathrm{HRMS} \mathrm{m} / \mathrm{z}$ calcd for $\mathrm{C}_{46} \mathrm{H}_{32} \mathrm{O}_{8} 713.2131[\mathrm{M}]$, found $713.2135[\mathrm{M}]^{+}$.

\section{Synthesis of 4.}



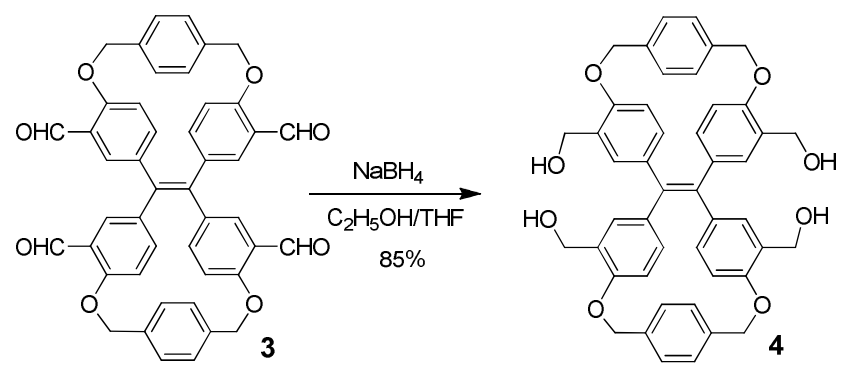

To a solution of $\mathbf{3}(250 \mathrm{mg}, 0.35 \mathrm{mmol})$ in $2: 3 \mathrm{THF} / \mathrm{EtOH}(\mathrm{V} / \mathrm{V}, 50 \mathrm{~mL})$ was carefully added $\mathrm{NaBH}_{4}(330 \mathrm{mg}, 8.77 \mathrm{mmol})$ under stirring. The resultant mixture was continued to stir at room temperature for $3 \mathrm{~h}$. Then water was added and the mixture was extracted with dichloromethane. The combined organic phase was dried over anhydrous $\mathrm{Na}_{2} \mathrm{SO}_{4}$, filtered and evaporated to dryness. The residue was subjected to column chromatography (silica gel, methanol / dichloromethane 1:30) to afford 4 as a white solid (214 mg, 85\%). Mp $=298.2-$ $299{ }^{\circ} \mathrm{C}:{ }^{1} \mathrm{H}$ NMR (400 MHz, DMSO-d $\left.{ }_{6}\right) \delta 7.29(\mathrm{~d}, J=8.5 \mathrm{~Hz}, 4 \mathrm{H}), 7.05(\mathrm{~d}, J=8.5 \mathrm{~Hz}, 4 \mathrm{H})$, 6.7 (s, 4H), $6.20-6.10(\mathrm{~m}, 8 \mathrm{H}), 5.28$ (d, $J=12.8 \mathrm{~Hz}, 4 \mathrm{H}), 5.13$ (d, $J=12.8 \mathrm{~Hz}, 4 \mathrm{H}), 4.91$ (t, $J$ $=5.4 \mathrm{~Hz}, 4 \mathrm{H}), 4.42(\mathrm{~d}, J=5.4 \mathrm{~Hz}, 8 \mathrm{H}) ;{ }^{13} \mathrm{C} \mathrm{NMR}\left(100 \mathrm{MHz}, \mathrm{DMSO}-\mathrm{d}_{6}\right) \delta 151.4,142.1$, 136.8, 135.7, 132.1, 130.9, 129.1, 127.6, 126.7, 115.3, 69.2, 58.6; IR (KBr) v 3428, 2924, 2880, 1604, 1494, 1254, 1216, 1124, 998, 811, $654 \mathrm{~cm}^{-1} ; \mathrm{ES}^{+} \mathrm{HRMS} \mathrm{m} / \mathrm{z}$ calcd for $\mathrm{C}_{46} \mathrm{H}_{40} \mathrm{O}_{8}$ $720.2723[\mathrm{M}]$, found $720.2688[\mathrm{M}]^{+}$.

\section{Synthesis of 5 .}
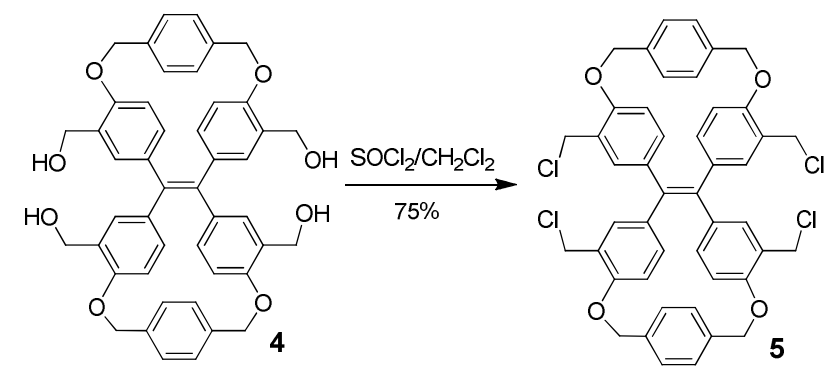

Freshly distilled thionyl chloride $(0.4 \mathrm{~mL}, 5.56 \mathrm{mmol})$ in dry dichloromethane $(30 \mathrm{~mL})$ was dropped into a solution of 4 (200 $\mathrm{mg}, 0.28 \mathrm{mmol})$, dry pyridine $(0.23 \mathrm{~mL}, 2,78 \mathrm{mmol})$ in dry dichloromethane $(30 \mathrm{~mL})$ in a iced bath under stirring over $0.5 \mathrm{~h}$. After the dropping was finished, the mixture was stirred at room temperature for $4 \mathrm{~h}$. Solvent was evaporated under reduced pressure to dryness, and water was added. The resultant mixture was extracted with dichloromethane three times. After the combined organic phase was dried over anhydrous $\mathrm{Na}_{2} \mathrm{SO}_{4}$, it was filtered and evaporated to dryness. The obtained crude product 5 was directly used in next step without further purification. 


\section{Synthesis of 6.}

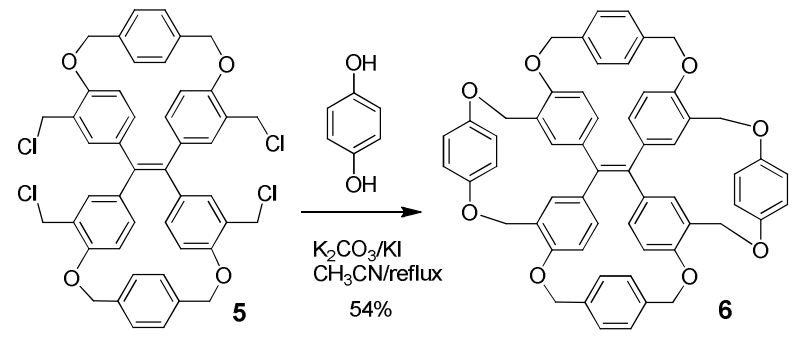

To a flask was added $5(150 \mathrm{mg}, 0.188 \mathrm{mmol})$, anhydrous $\mathrm{K}_{2} \mathrm{CO}_{3}(91 \mathrm{mg}, 0.66 \mathrm{mmol})$, potassium iodide (150 mg, $0.90 \mathrm{mmol})$, 1,4-benzenediol $(62 \mathrm{mg}, 0.56 \mathrm{mmol})$, and dry acetonitrile $(120 \mathrm{~mL})$. The resultant mixture was refluxed for $10 \mathrm{~h}$. After solvent was removed, water and dichloromethane were added to give a solution with two phases. Before the water phase was extracted two times with dichloromethane, the organic phase was separated. The combined organic phase was dried over anhydrous $\mathrm{Na}_{2} \mathrm{SO}_{4}$, filtered and evaporated to dryness. The residue was subjected to column chromatography (silica gel, ethyl acetate / dichloromethane 1:50) to afford 6 as a white solid (88 mg, 54\%).

Racemic 6: $\mathrm{Mp}>280{ }^{\circ} \mathrm{C}$ (decomposed); ${ }^{1} \mathrm{H}$ NMR $\left(400 \mathrm{MHz}, \mathrm{DMSO}-\mathrm{d}_{6}\right) \delta 7.32(\mathrm{~d}, J=8.7 \mathrm{~Hz}$, 4H), 7.05 (d, $J=8.7 \mathrm{~Hz}, 4 \mathrm{H}), 6.85$ (dd, $J=8.7 \mathrm{~Hz}, J=3.0 \mathrm{~Hz}, 4 \mathrm{H}), 6.11(\mathrm{~d}, J=8.7 \mathrm{~Hz}, 4 \mathrm{H})$, $6.06(\mathrm{dd}, J=8.7 \mathrm{~Hz}, J=3.0 \mathrm{~Hz}, 4 \mathrm{H}), 5.91(\mathrm{dd}, J=8.7 \mathrm{~Hz}, J=2.0 \mathrm{~Hz}, 4 \mathrm{H}), 5.83(\mathrm{~d}, J=2.0$ $\mathrm{Hz}, 4 \mathrm{H}), 5.41$ (d, $J=12.8 \mathrm{~Hz}, 4 \mathrm{H}), 5.33$ (d, $J=11.6 \mathrm{~Hz}, 4 \mathrm{H}), 5.16$ (d, $J=12.8 \mathrm{~Hz}, 4 \mathrm{H}), 4.56$ $(\mathrm{d}, J=11.6 \mathrm{~Hz}, 4 \mathrm{H}) ;{ }^{13} \mathrm{C}$ NMR $\left(100 \mathrm{MHz}, \mathrm{DMSO}-\mathrm{d}_{6}\right) \delta 153.4,152.8,140.2,136.7,134.4$, 134.0, 132.9, 132.5, 127.1, 123.7, 123.6, 121.8, 116.4, 69.7, 69.5; IR (KBr) v 3455, 2928, 2880, 1604, 1497, 1298, 1247, 1216, 1185, 1127, 997, 959, 812, $658 \mathrm{~cm}^{-1} ; \mathrm{ES}^{+} \mathrm{HRMS} \mathrm{m/z}$ calcd for $\mathrm{C}_{58} \mathrm{H}_{44} \mathrm{O}_{8} 868.3036[\mathrm{M}]$, found $869.3073[\mathrm{M}+1]^{+}$.

M-6: $[\alpha]^{25}{ }_{\mathrm{D}}=+479(5 \mathrm{mg} / \mathrm{mL}, \mathrm{THF}) ; \mathrm{Mp}>280{ }^{\circ} \mathrm{C}$ (decomposed); ${ }^{1} \mathrm{H}$ NMR $(400 \mathrm{MHz}$, DMSO-d $\left._{6}\right) \delta 7.31(\mathrm{~d}, J=8.7 \mathrm{~Hz}, 4 \mathrm{H}), 7.05(\mathrm{~d}, J=8.7 \mathrm{~Hz}, 4 \mathrm{H}), 6.85(\mathrm{dd}, J=8.7 \mathrm{~Hz}, J=3.0$ $\mathrm{Hz}, 4 \mathrm{H}), 6.11(\mathrm{~d}, J=8.7 \mathrm{~Hz}, 4 \mathrm{H}), 6.06(\mathrm{dd}, J=8.7 \mathrm{~Hz}, J=3.0 \mathrm{~Hz}, 4 \mathrm{H}), 5.91(\mathrm{dd}, J=8.7 \mathrm{~Hz}$, $J=2.0 \mathrm{~Hz}, 4 \mathrm{H}), 5.83(\mathrm{~d}, J=2.0 \mathrm{~Hz}, 4 \mathrm{H}), 5.40(\mathrm{~d}, J=12.8 \mathrm{~Hz}, 4 \mathrm{H}), 5.33(\mathrm{~d}, J=11.6 \mathrm{~Hz}, 4 \mathrm{H})$, $5.16(\mathrm{~d}, J=12.8 \mathrm{~Hz}, 4 \mathrm{H}), 4.56(\mathrm{~d}, J=11.6 \mathrm{~Hz}, 4 \mathrm{H}) ;{ }^{13} \mathrm{C}$ NMR $\left(100 \mathrm{MHz}, \mathrm{DMSO}-\mathrm{d}_{6}\right) \delta 153.4$, 152.8, 140.2, 136.7, 134.4, 134.0, 132.9, 132.5, 127.1, 123.7, 123.6, 121.8, 116.4, 69.7, 69.5; IR $(\mathrm{KBr}) v 3454,2928,2880,1605,1497,1298,1246,1215,1185,1127,999,960,812,657$ $\mathrm{cm}^{-1} ; \mathrm{ES}^{+} \mathrm{HRMS} \mathrm{m} / \mathrm{z}$ calcd for $\mathrm{C}_{58} \mathrm{H}_{44} \mathrm{O}_{8} 868.3036$ [M], found $869.3055[\mathrm{M}+1]^{+}$.

P-6: $[\alpha]^{25}{ }_{\mathrm{D}}=-502(5 \mathrm{mg} / \mathrm{mL}, \mathrm{THF}) ; \mathrm{Mp}>280{ }^{\circ} \mathrm{C}$ (decomposed); ${ }^{1} \mathrm{H}$ NMR $(400 \mathrm{MHz}$, DMSO-d $\left._{6}\right) \delta 7.32(\mathrm{~d}, J=8.7 \mathrm{~Hz}, 4 \mathrm{H}), 7.05(\mathrm{~d}, J=8.7 \mathrm{~Hz}, 4 \mathrm{H}), 6.85(\mathrm{dd}, J=8.7 \mathrm{~Hz}, J=3.0$ $\mathrm{Hz}, 4 \mathrm{H}), 6.11(\mathrm{~d}, J=8.7 \mathrm{~Hz}, 4 \mathrm{H}), 6.06(\mathrm{dd}, J=8.7 \mathrm{~Hz}, J=3.0 \mathrm{~Hz}, 4 \mathrm{H}), 5.91$ (dd, $J=8.7 \mathrm{~Hz}$, 
$J=2.0 \mathrm{~Hz}, 4 \mathrm{H}), 5.83(\mathrm{~d}, J=2.0 \mathrm{~Hz}, 4 \mathrm{H}), 5.41(\mathrm{~d}, J=12.8 \mathrm{~Hz}, 4 \mathrm{H}), 5.33(\mathrm{~d}, J=11.6 \mathrm{~Hz}, 4 \mathrm{H})$, $5.17(\mathrm{~d}, J=12.8 \mathrm{~Hz}, 4 \mathrm{H}), 4.56(\mathrm{~d}, J=11.6 \mathrm{~Hz}, 4 \mathrm{H}) ;{ }^{13} \mathrm{C}$ NMR $\left(100 \mathrm{MHz}, \mathrm{DMSO}-\mathrm{d}_{6}\right) \delta 153.4$, 152.8, 140.2, 136.7, 134.4, 134.0, 132.9, 132.5, 127.1, 123.7, 123.6, 121.8, 116.4, 69.7, 69.5; IR (KBr) v 3451, 2927, 2881, 1602, 1497, 1298, 1251, 1216, 1187, 1126, 1095, 1003, 960, $809,656 \mathrm{~cm}^{-1}$; $\mathrm{ES}^{+} \mathrm{HRMS} \mathrm{m} / \mathrm{z}$ calcd for $\mathrm{C}_{58} \mathrm{H}_{44} \mathrm{O}_{8} 868.3036[\mathrm{M}]$, found $869.3064[\mathrm{M}+1]^{+}$.

${ }^{1} \mathrm{H} /{ }^{13} \mathrm{C}-\mathrm{NMR}$, IR and HRMS spectra of compound $2,3,4,6$, M-6, and P-6.

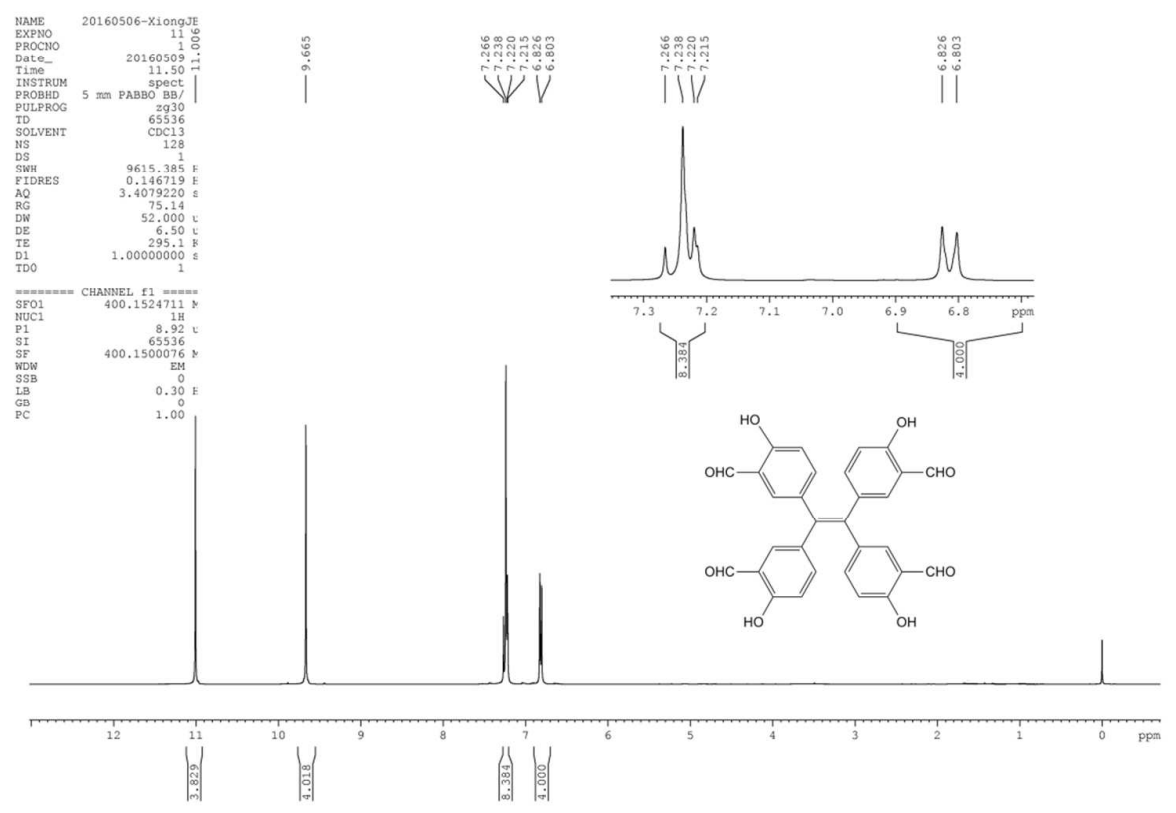

Fig. S1. ${ }^{1} \mathrm{H}$ NMR spectrum of compound 2 in $\mathrm{CDCl}_{3}$. 


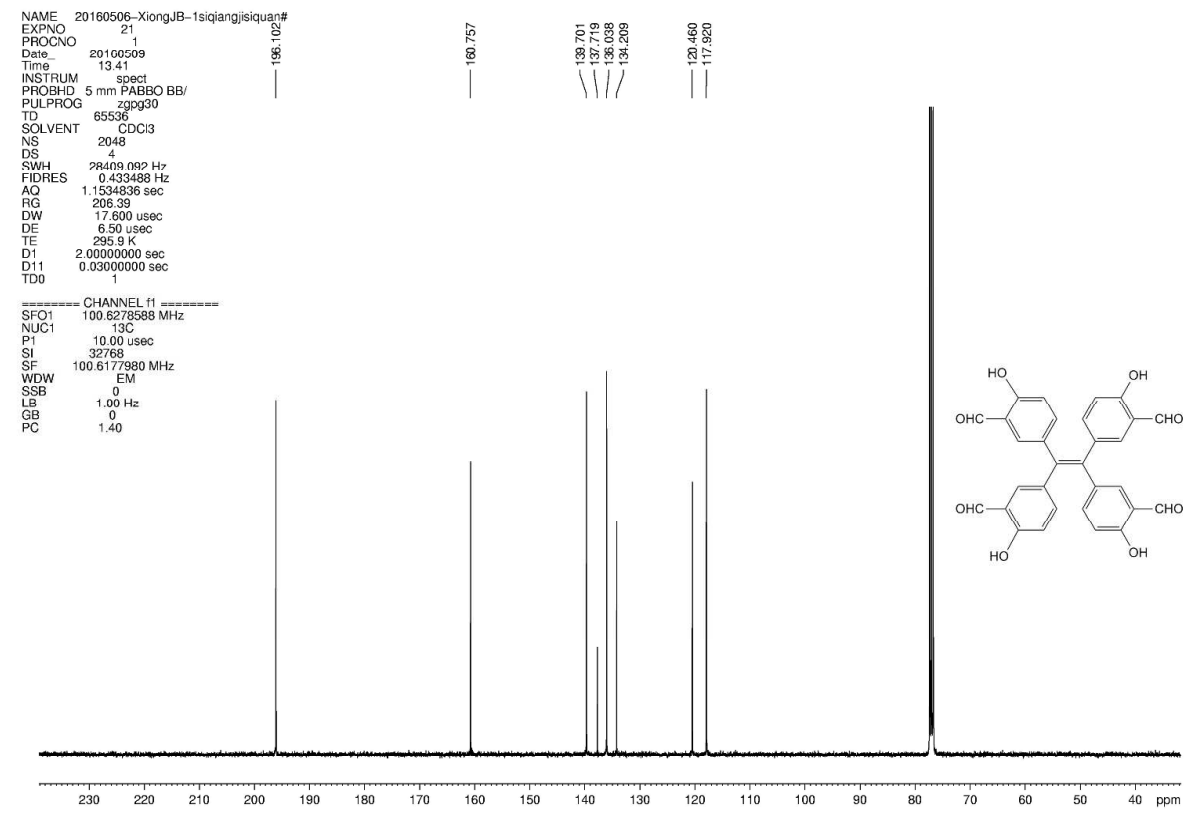

Fig. S2. ${ }^{13} \mathrm{C}$ NMR spectrum of compound 2 in $\mathrm{CDCl}_{3}$.

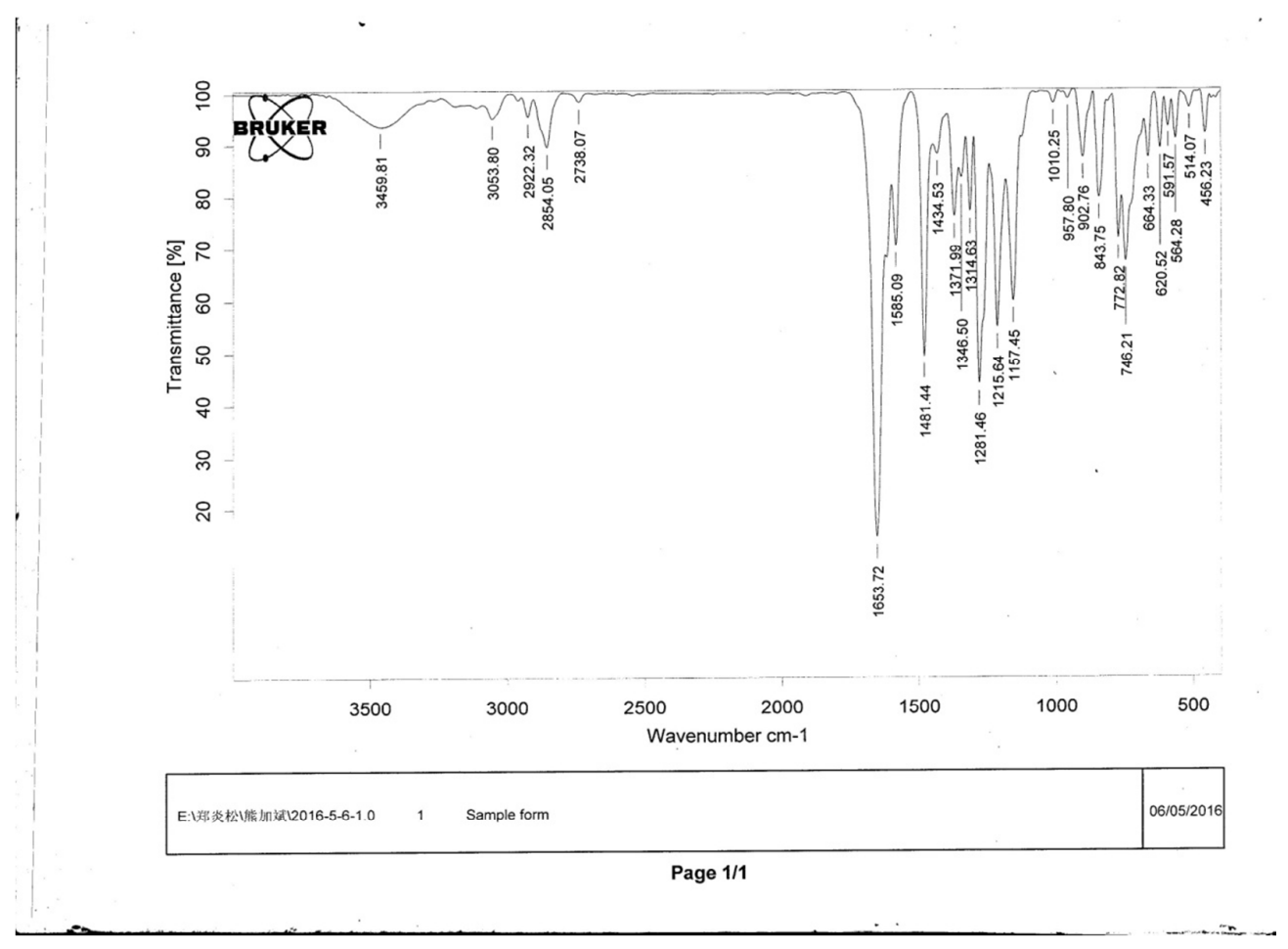

Fig. S3. IR spectrum of compound 2. 


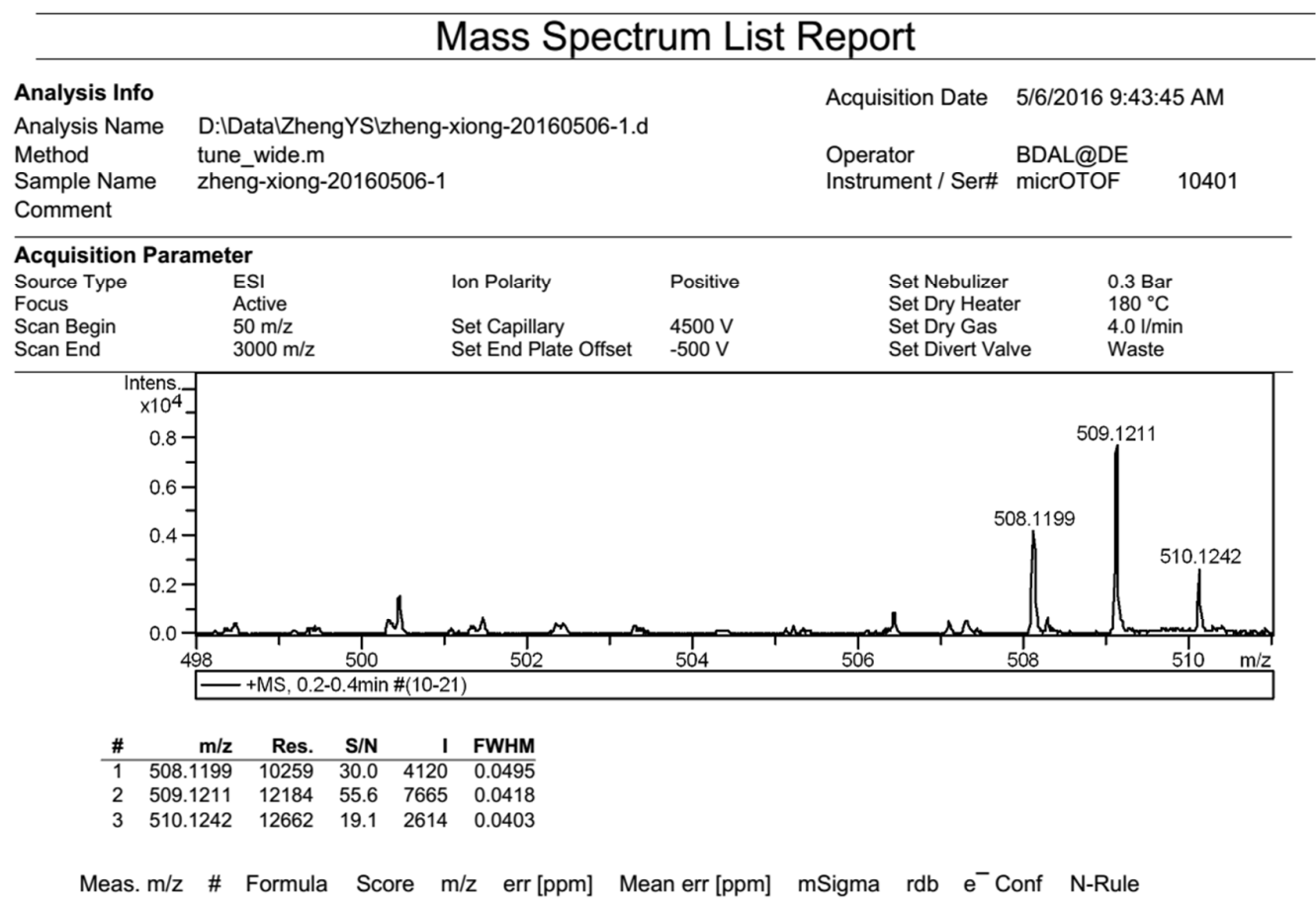

Fig. S4. HRMS spectrum of compound 2. 


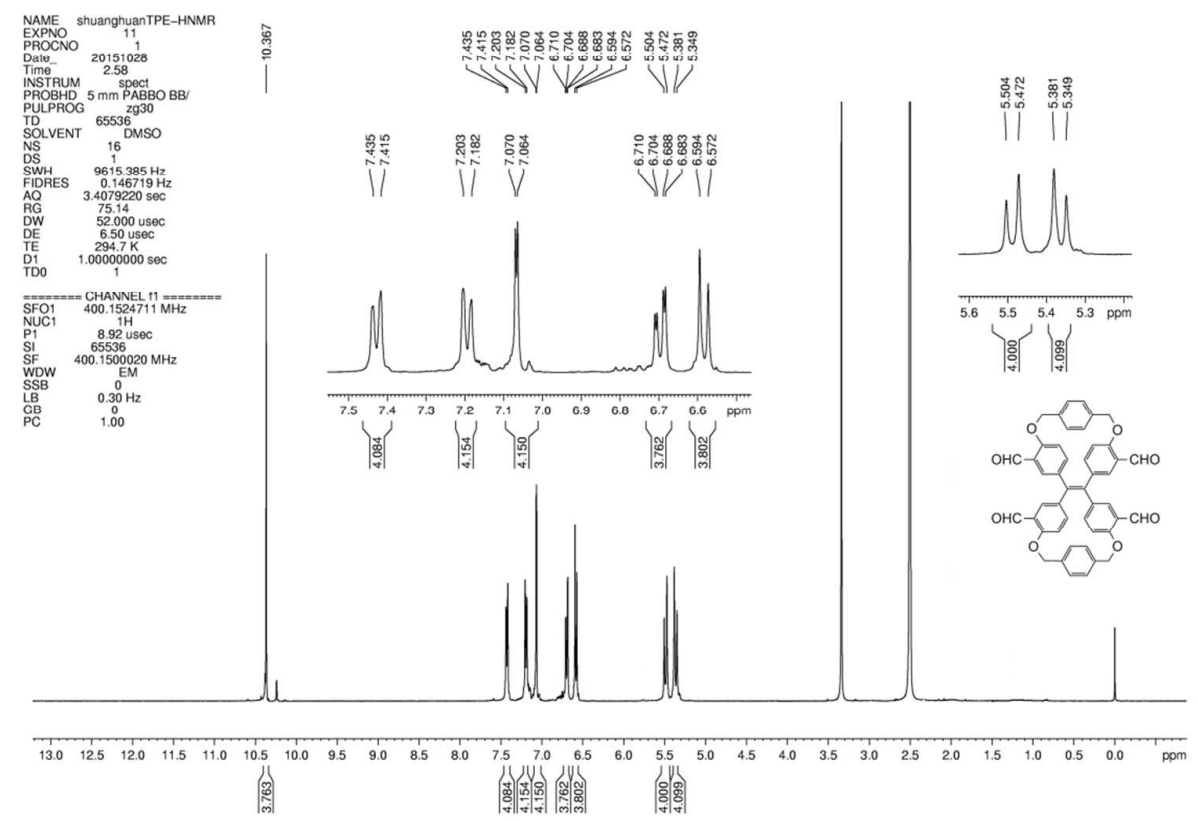

Fig. S5. ${ }^{1} \mathrm{H}$ NMR spectrum of compound 3 in DMSO-d $\mathrm{d}_{6}$.

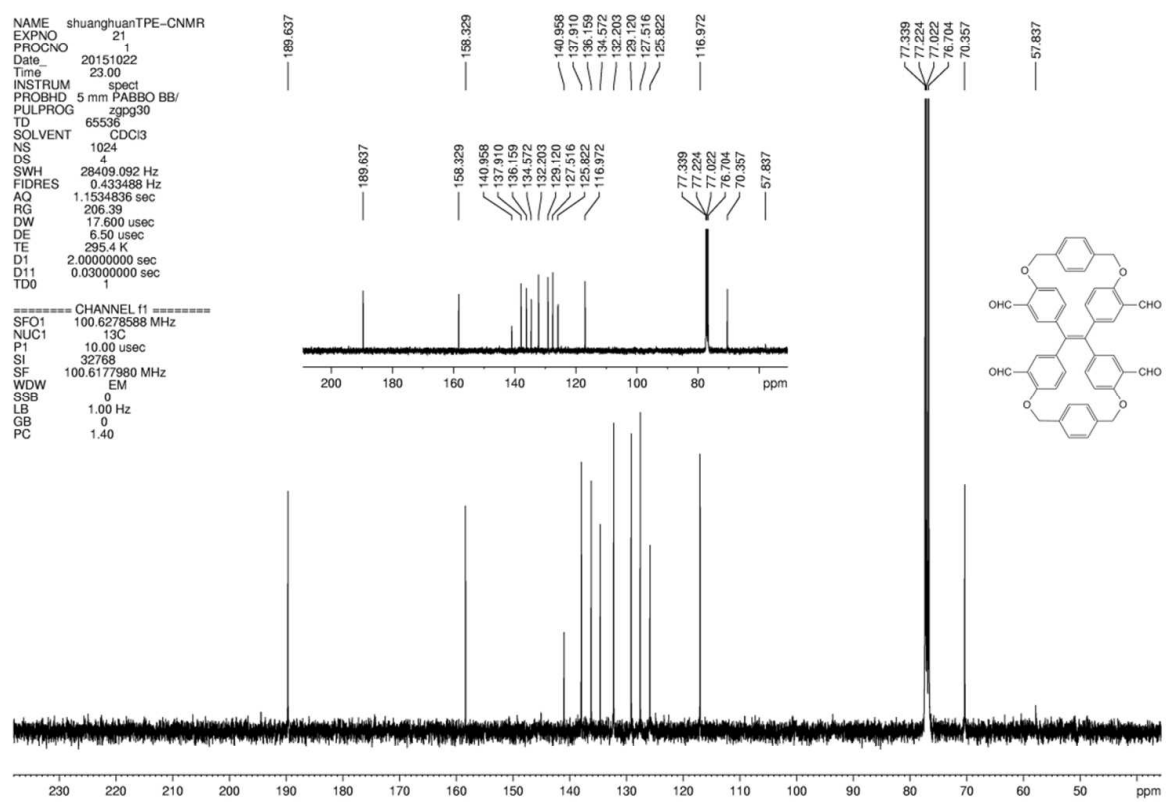

Fig. S6. ${ }^{13} \mathrm{C}$ NMR spectrum of compound 3 in DMSO- $\mathrm{d}_{6}$. 


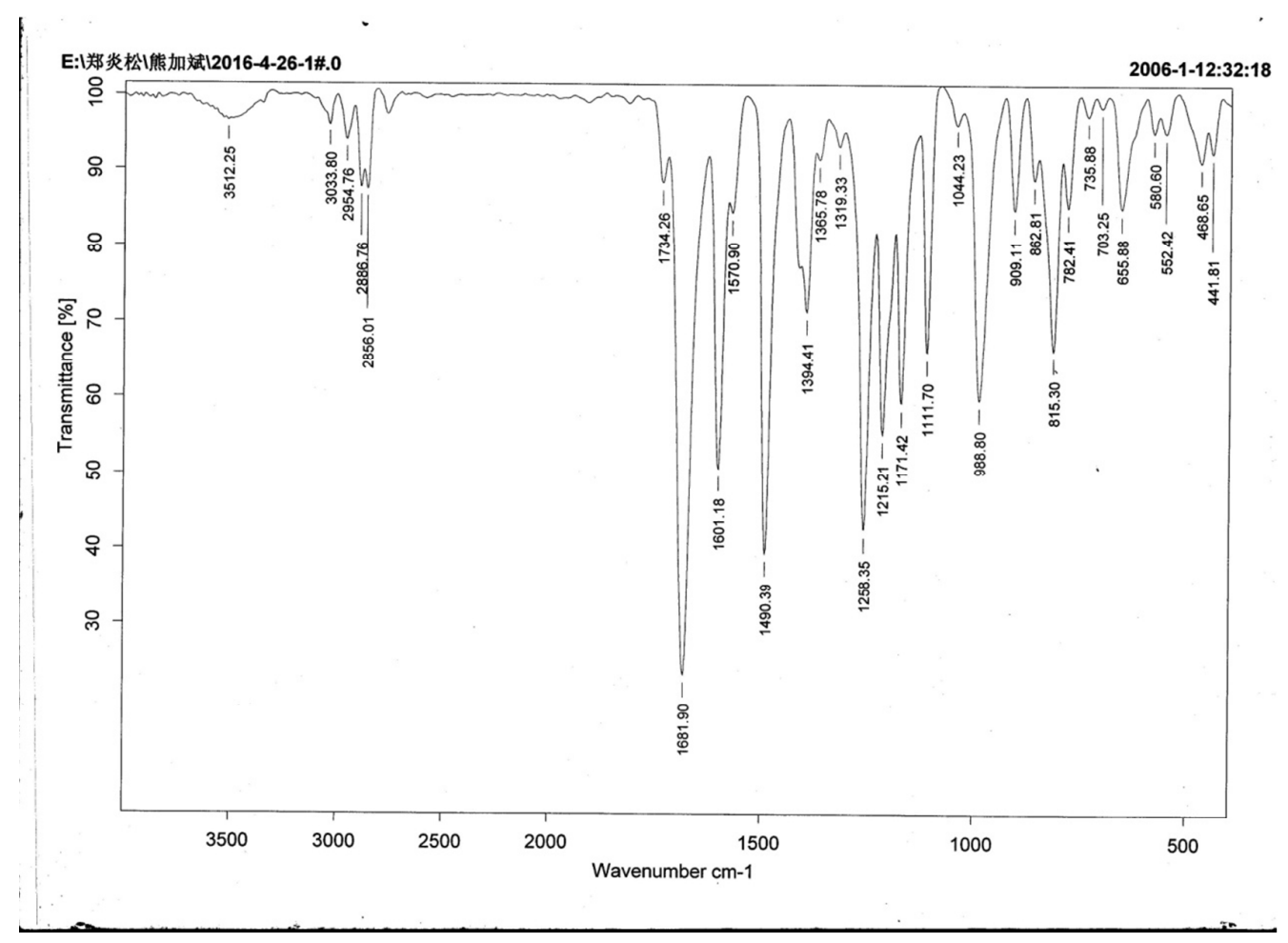

Fig. S7. IR spectrum of compound 3. 


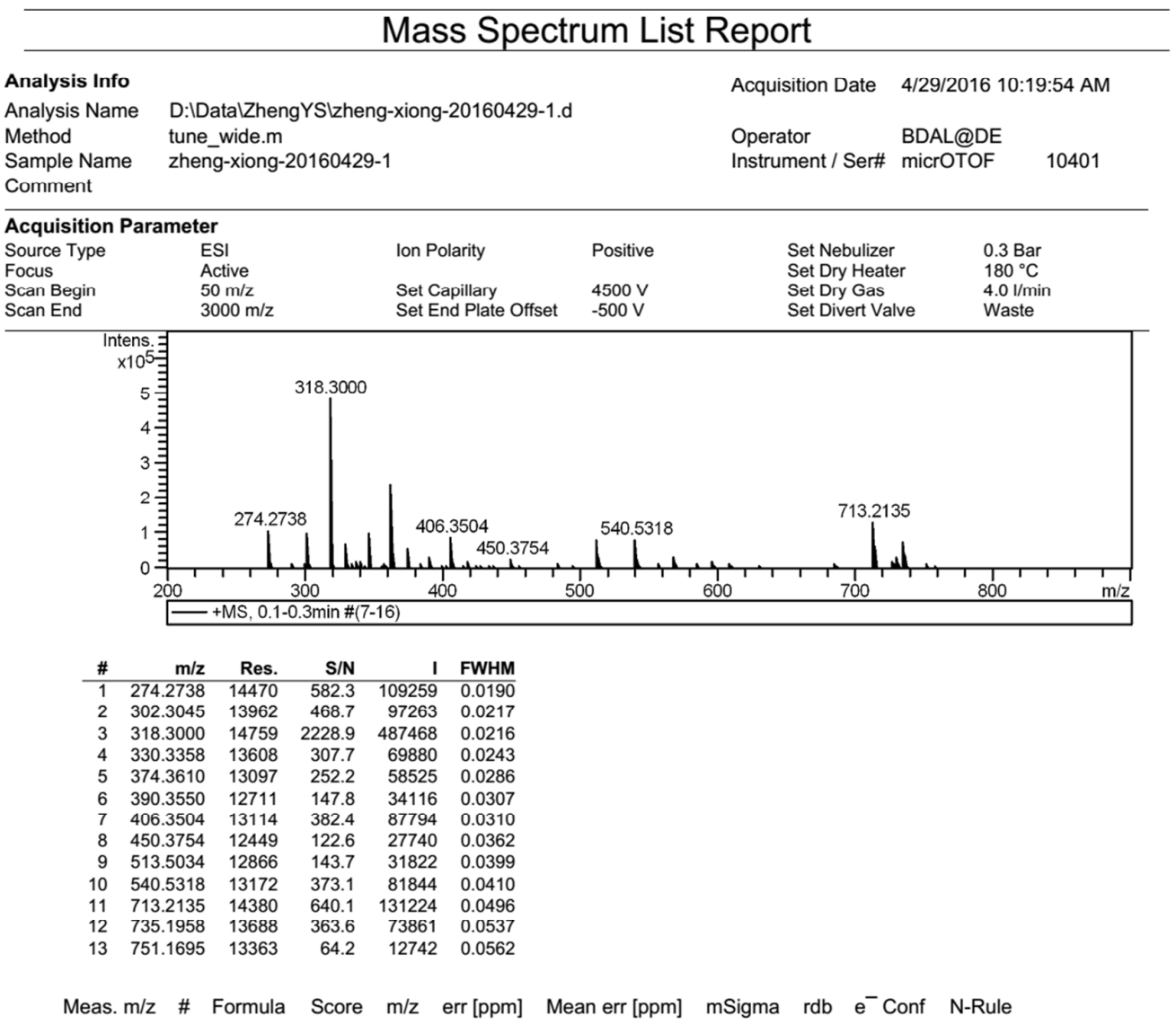

\begin{tabular}{llll}
\hline Bruker Compass DataAnalysis 4.0 & printed: & 4/29/2016 11:57:48 AM & Page 1 of 1
\end{tabular}

Fig. S8. HRMS spectrum of compound 3. 


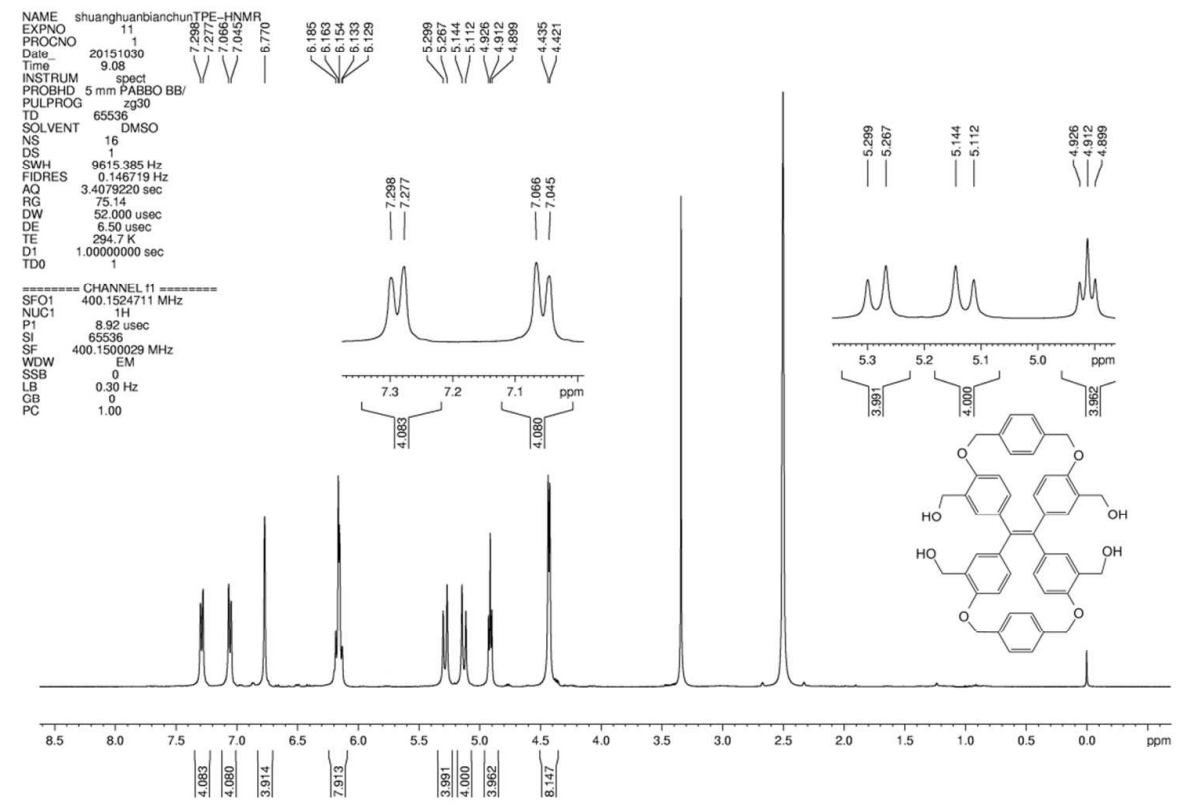

Fig. S9. ${ }^{1} \mathrm{H}$ NMR spectrum of compound 4 in $\mathrm{DMSO}^{-} \mathrm{d}_{6}$.

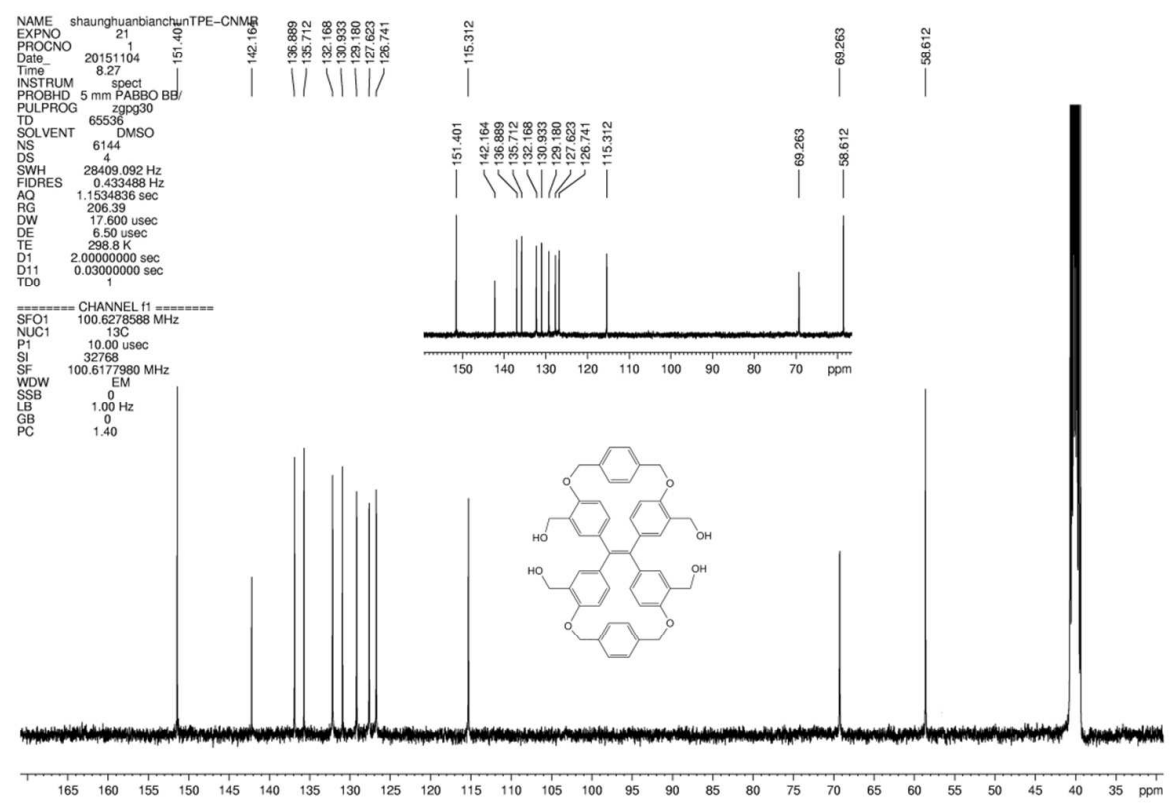

Fig. S10. ${ }^{13} \mathrm{C}$ NMR spectrum of compound 4 in DMSO-d ${ }_{6}$. 


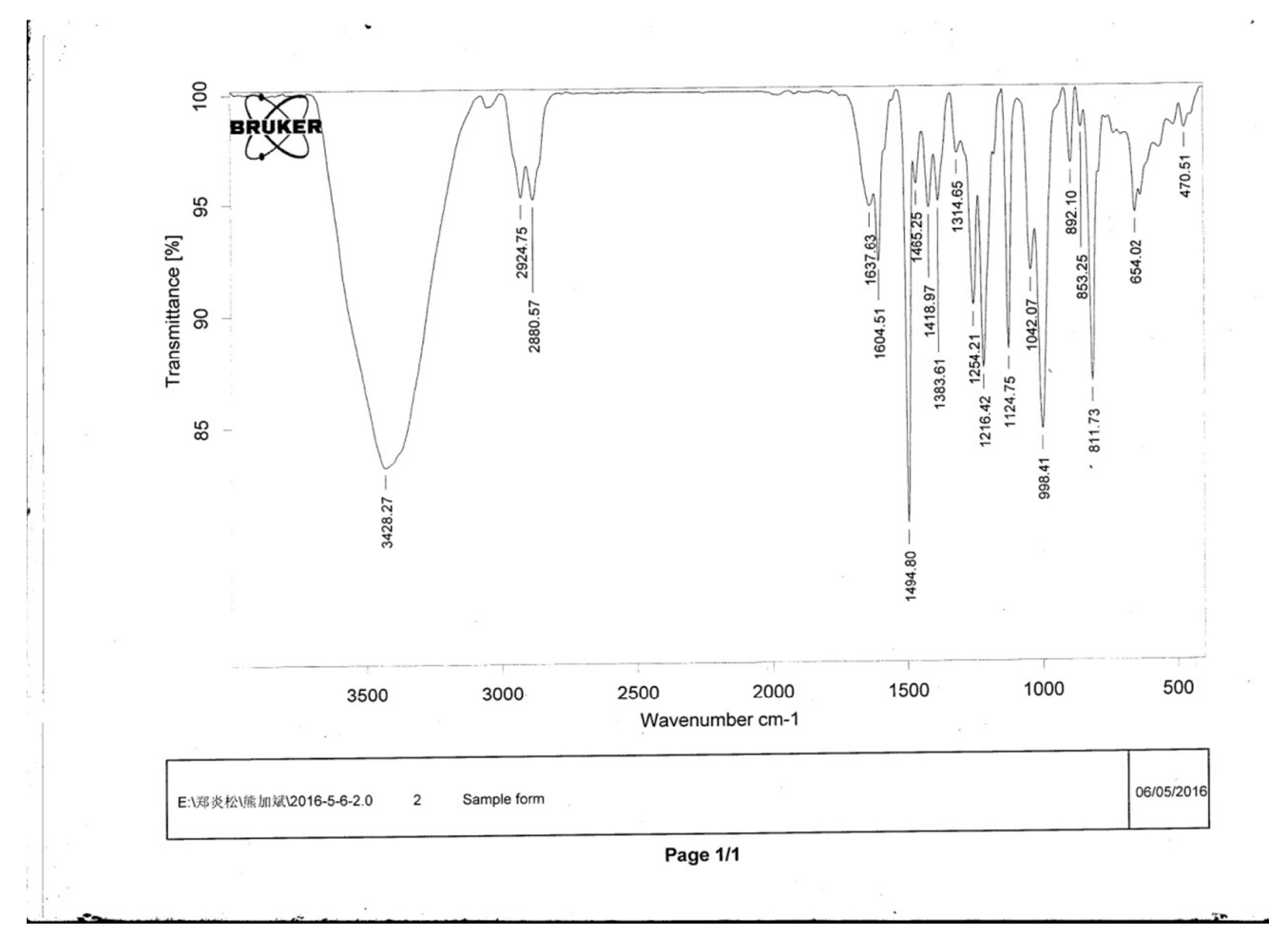

Fig. S11. IR spectrum of compound 4. 


\section{Mass Spectrum List Report}

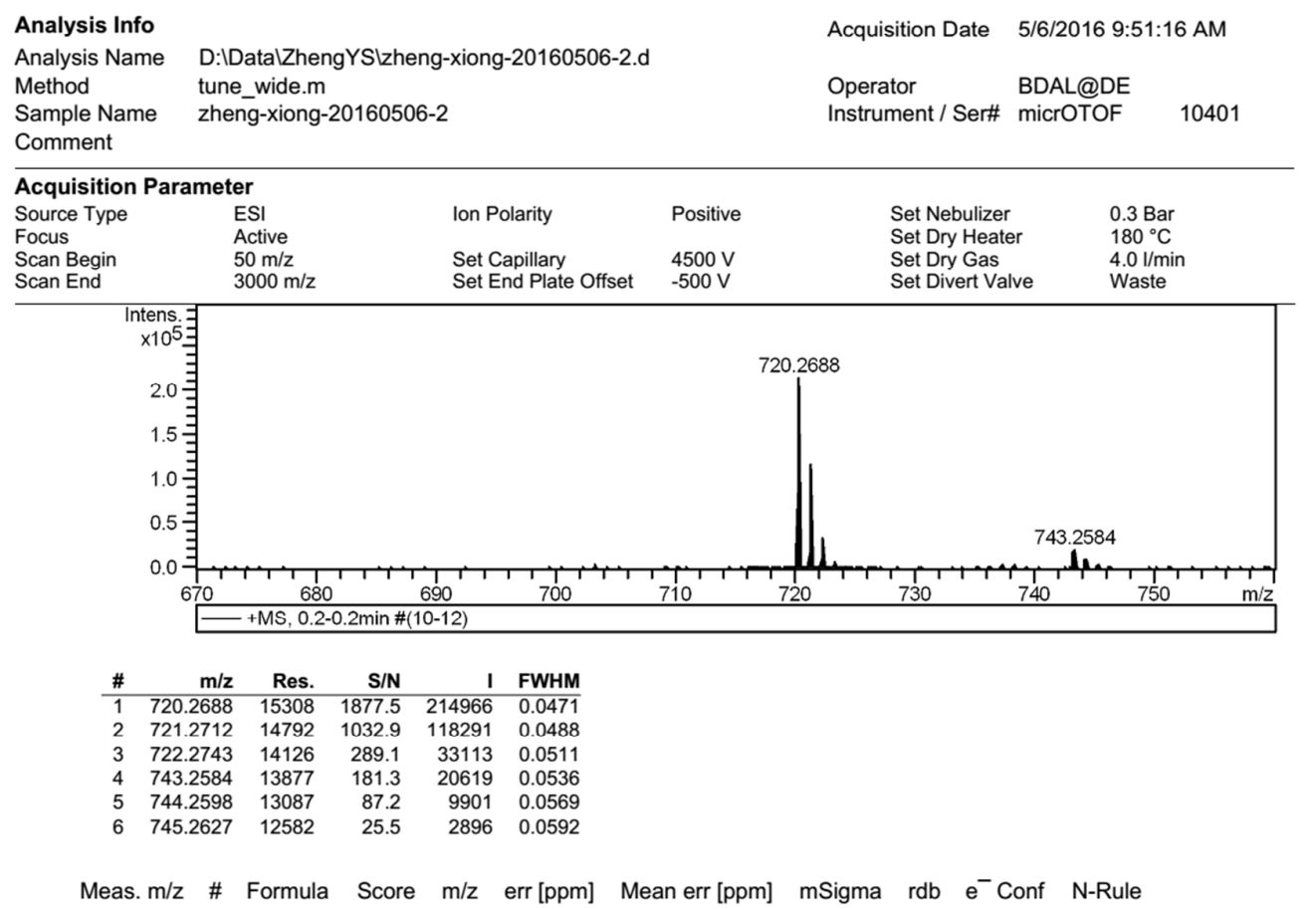

Fig. S12. HRMS spectrum of compound 4. 


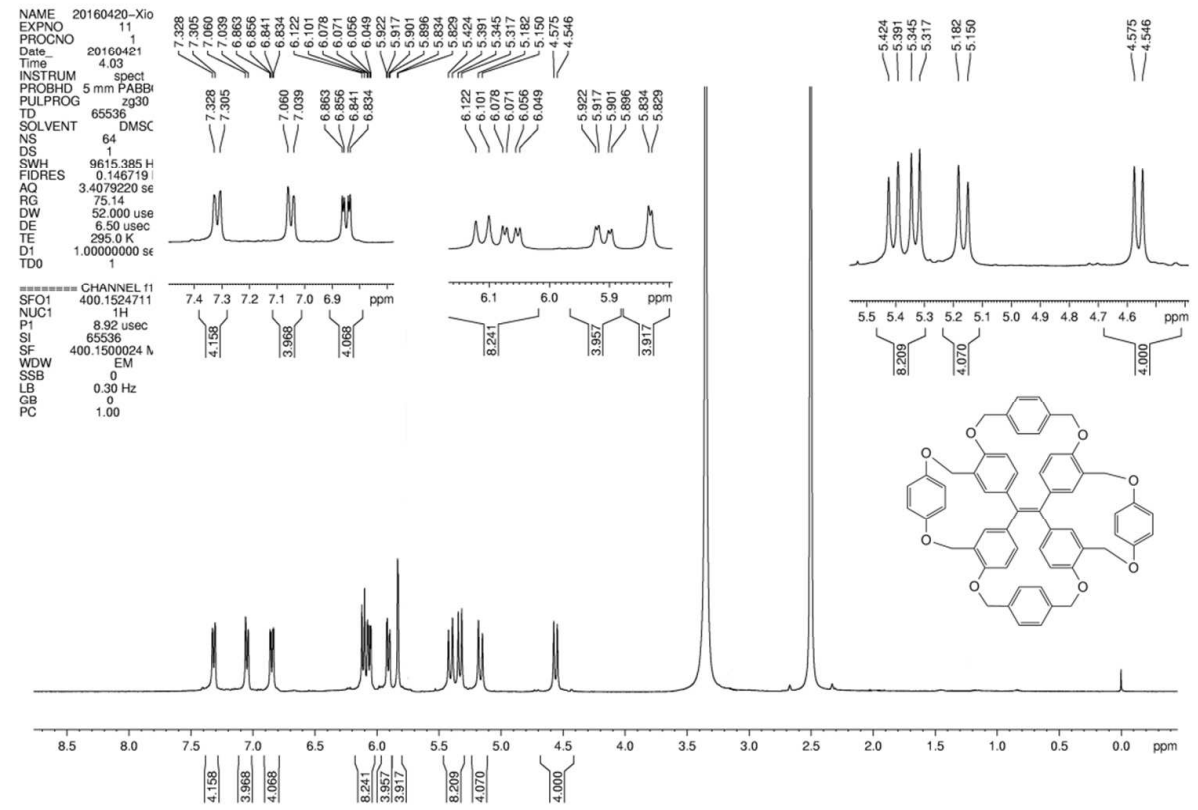

Fig. S13. ${ }^{1} \mathrm{H}$ NMR spectrum of racemic 6 in $\mathrm{DMSO}^{-} \mathrm{d}_{6}$.

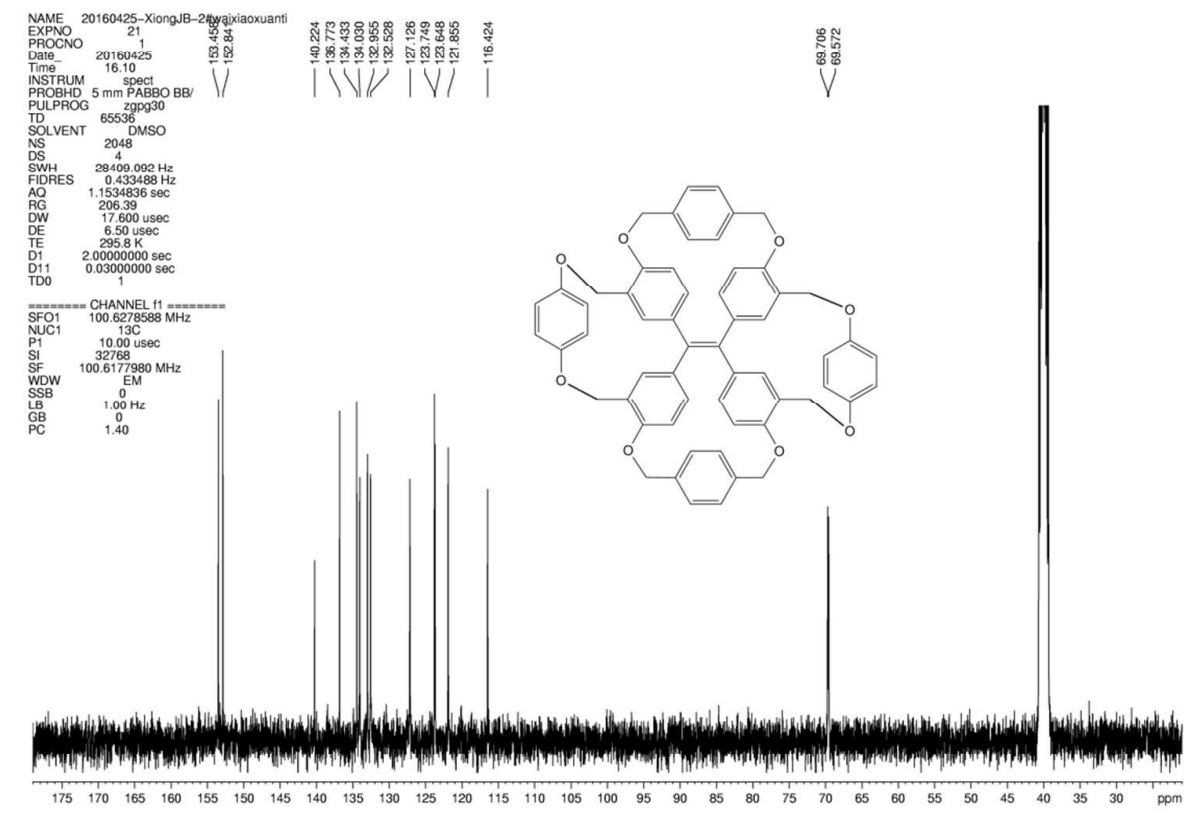

Fig. S14. ${ }^{13} \mathrm{C}$ NMR spectrum of racemic 6 in DMSO-d 6 . 


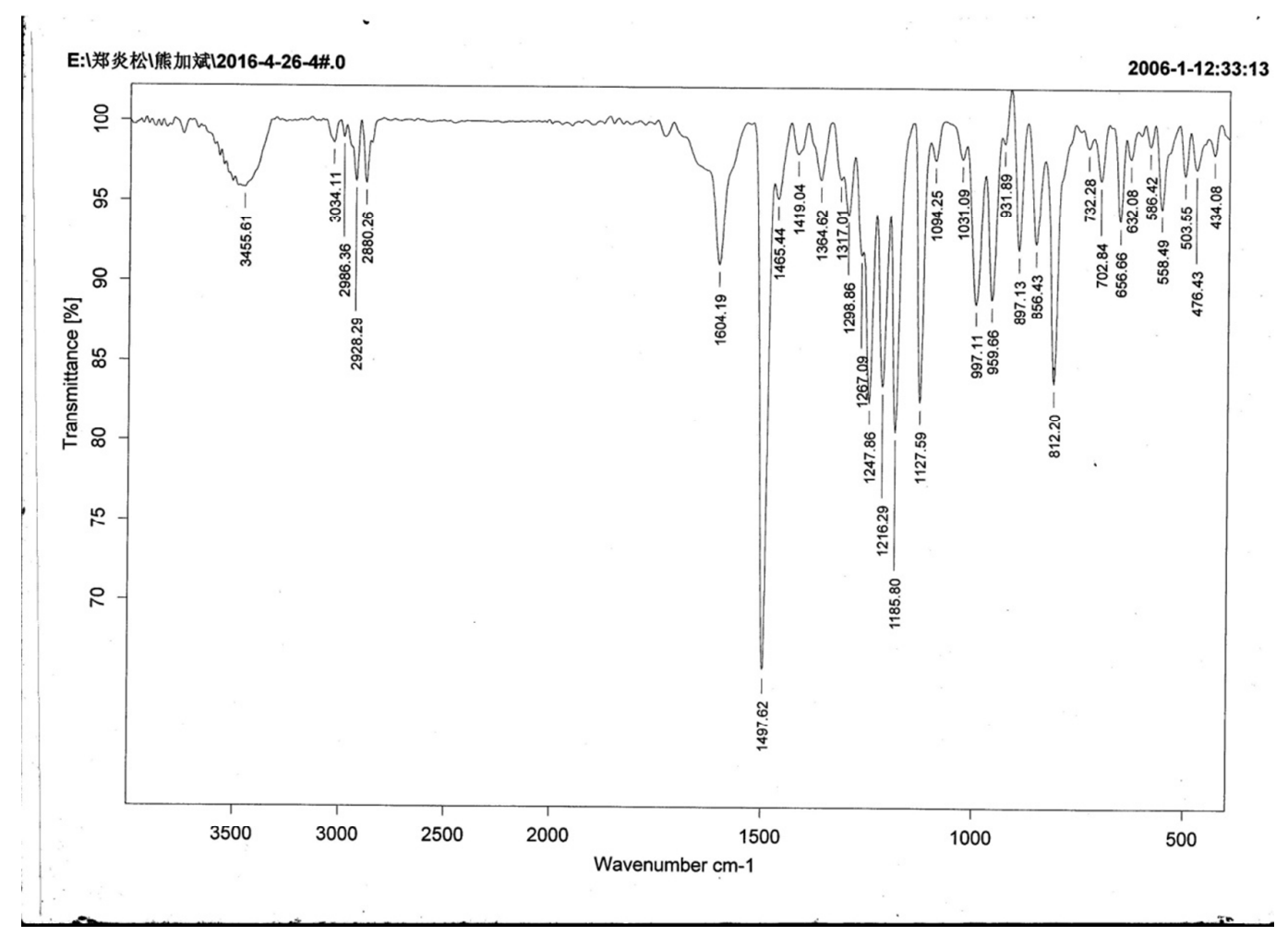

Fig. S15. IR spectrum of racemic 6. 


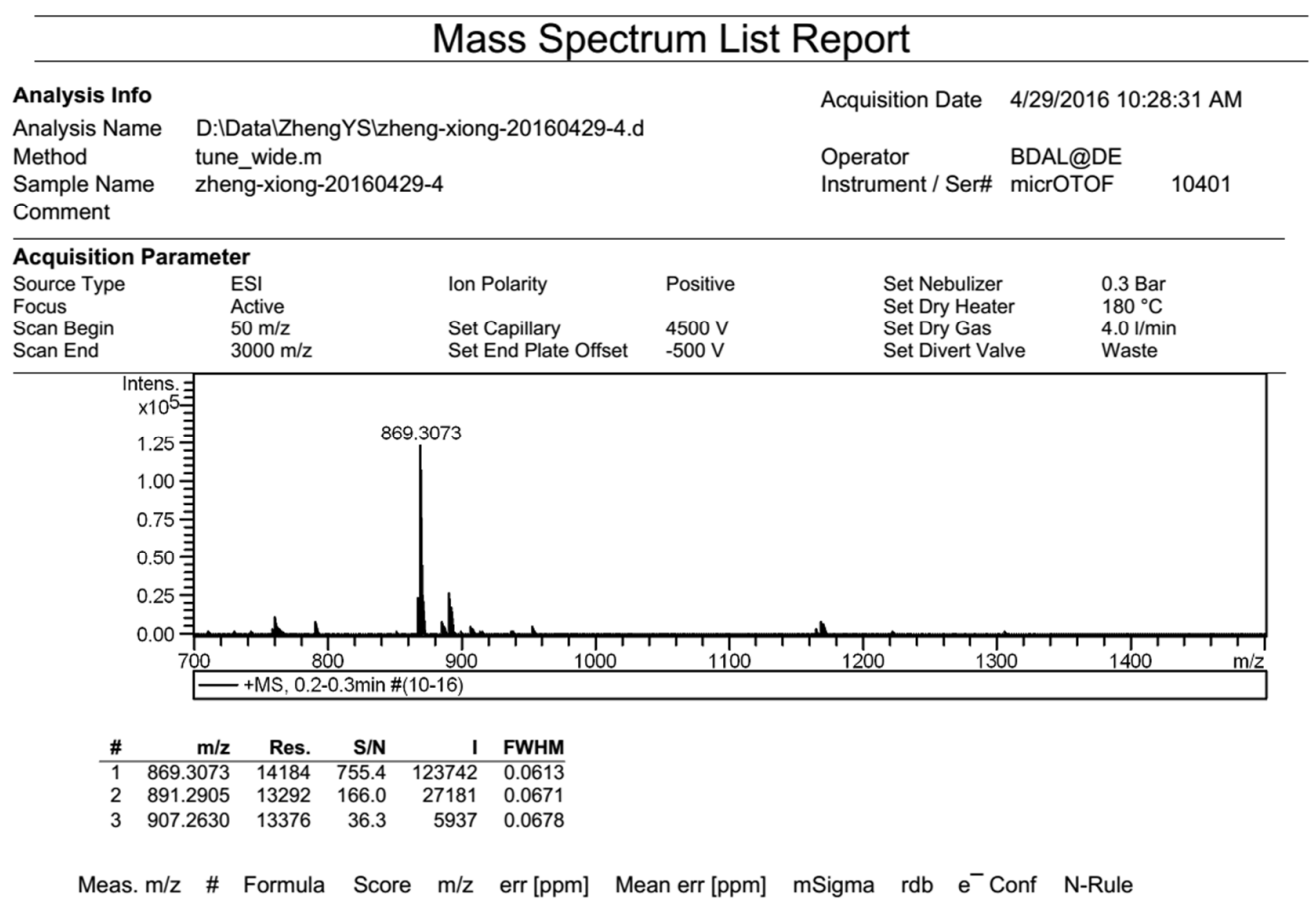

\begin{tabular}{llll}
\hline Bruker Compass DataAnalysis 4.0 & printed: & 4/29/2016 12:07:46 PM & Page 1 of 1
\end{tabular}

Fig. S16. HRMS spectrum of racemic 6. 


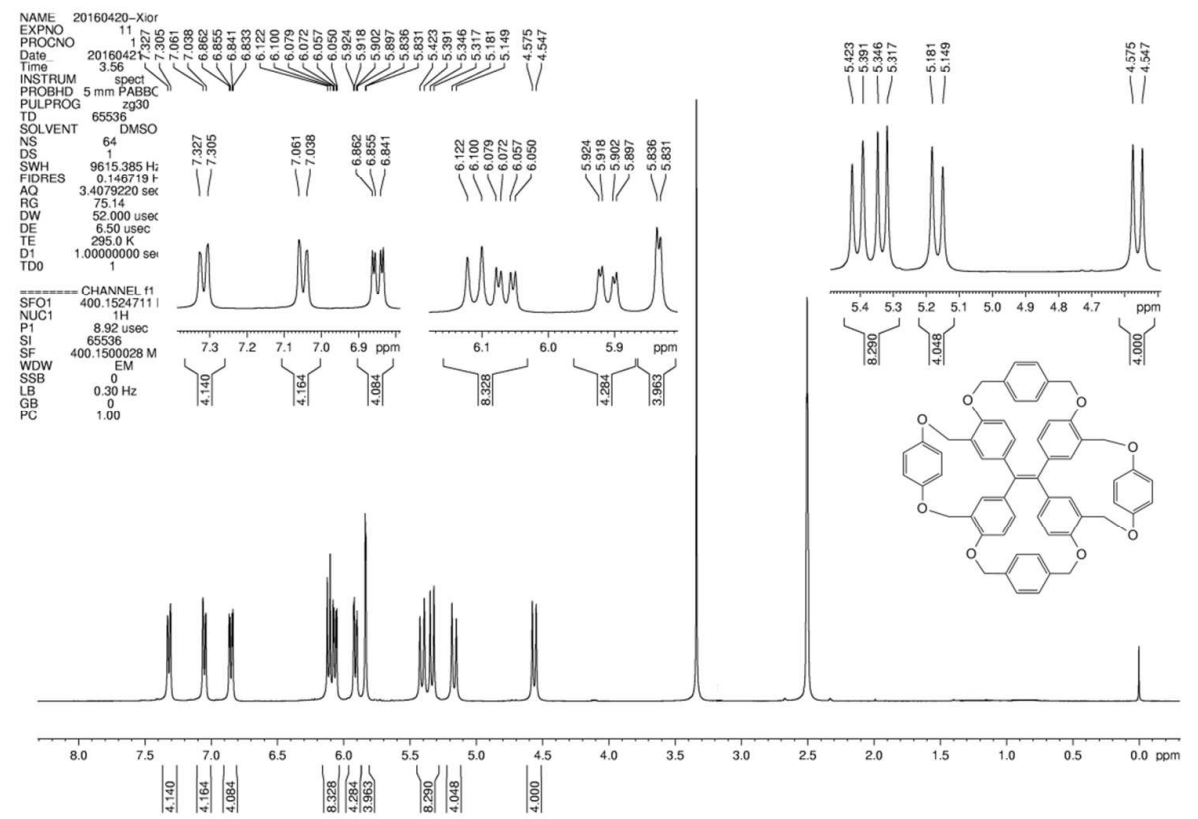

Fig. S17. ${ }^{1} \mathrm{H}$ NMR spectrum of M-6 in DMSO-d 6 .

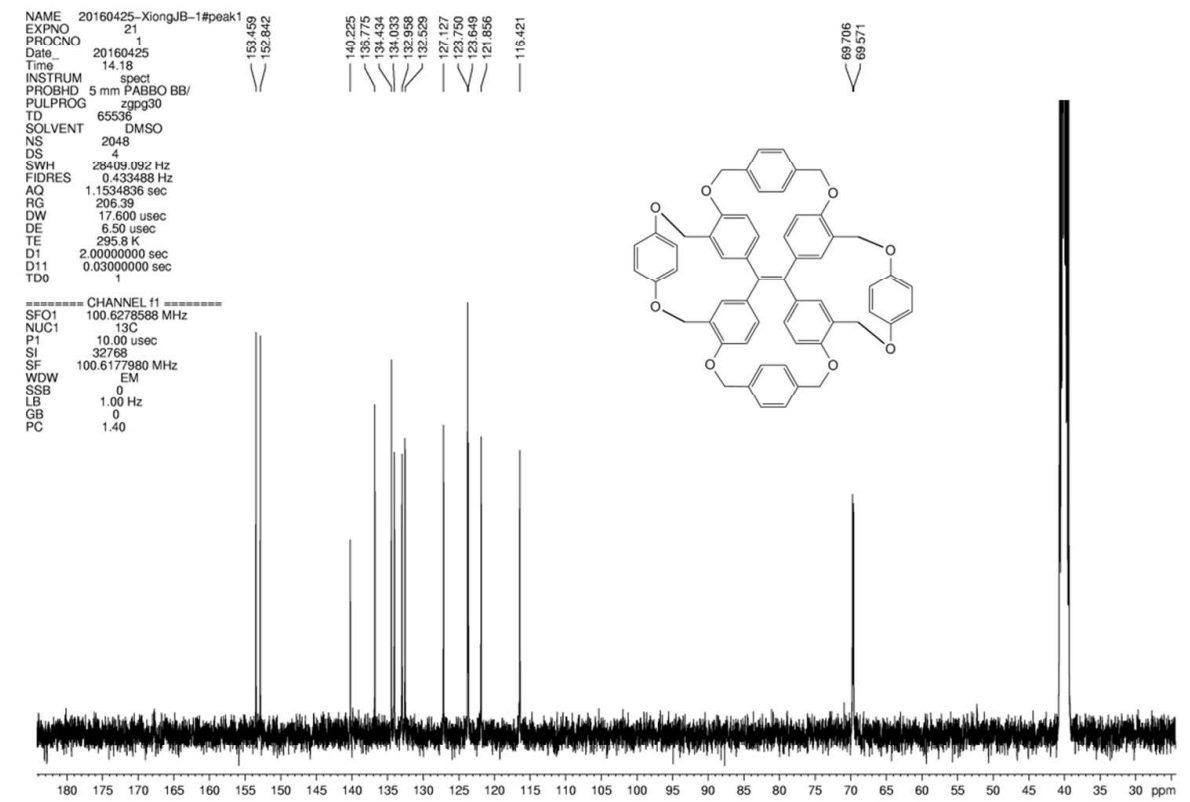

Fig. S18. ${ }^{13} \mathrm{C}$ NMR spectrum of M-6 in DMSO-d $\mathrm{d}_{6}$. 


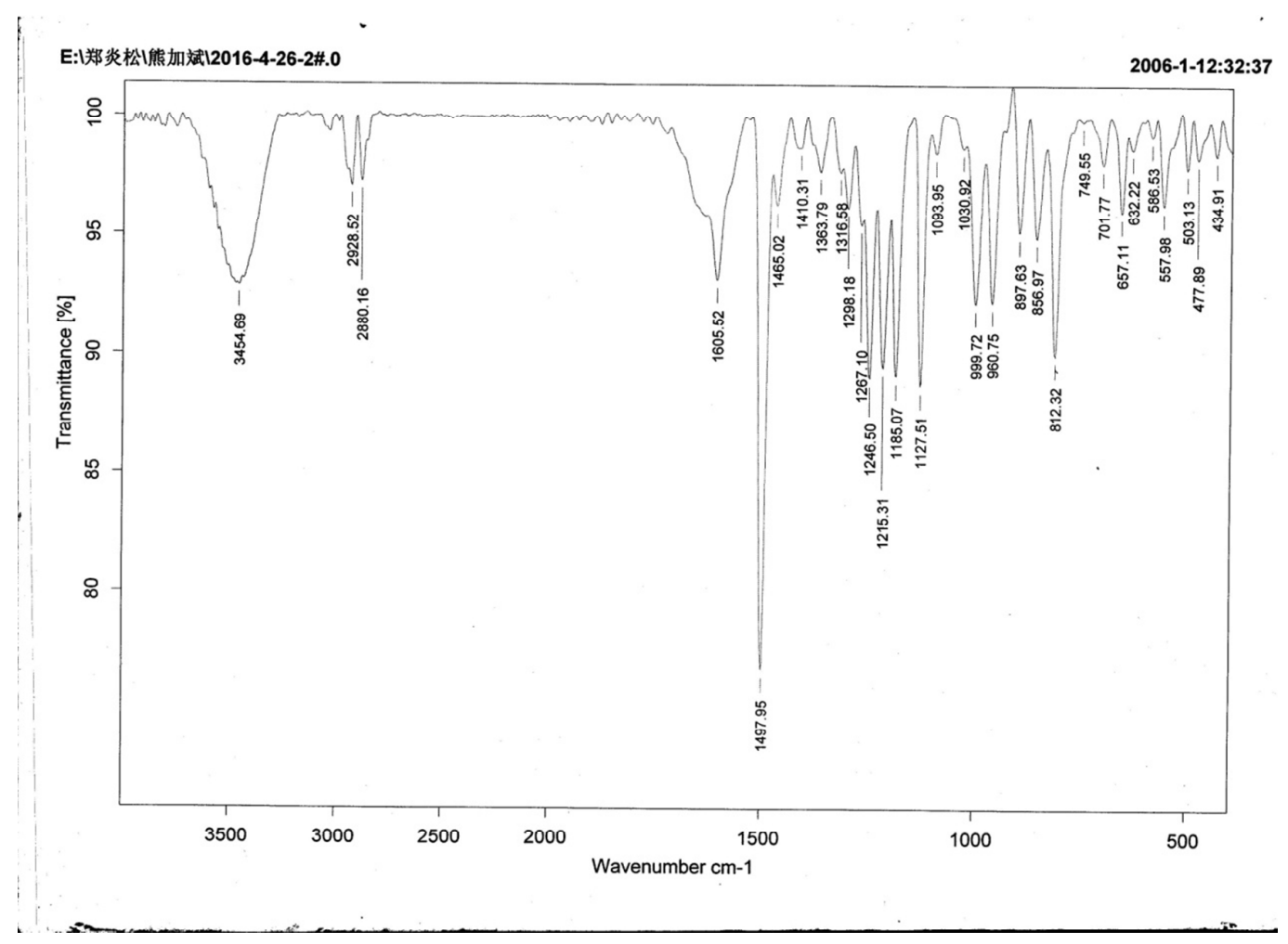

Fig. S19. IR spectrum of M-6. 


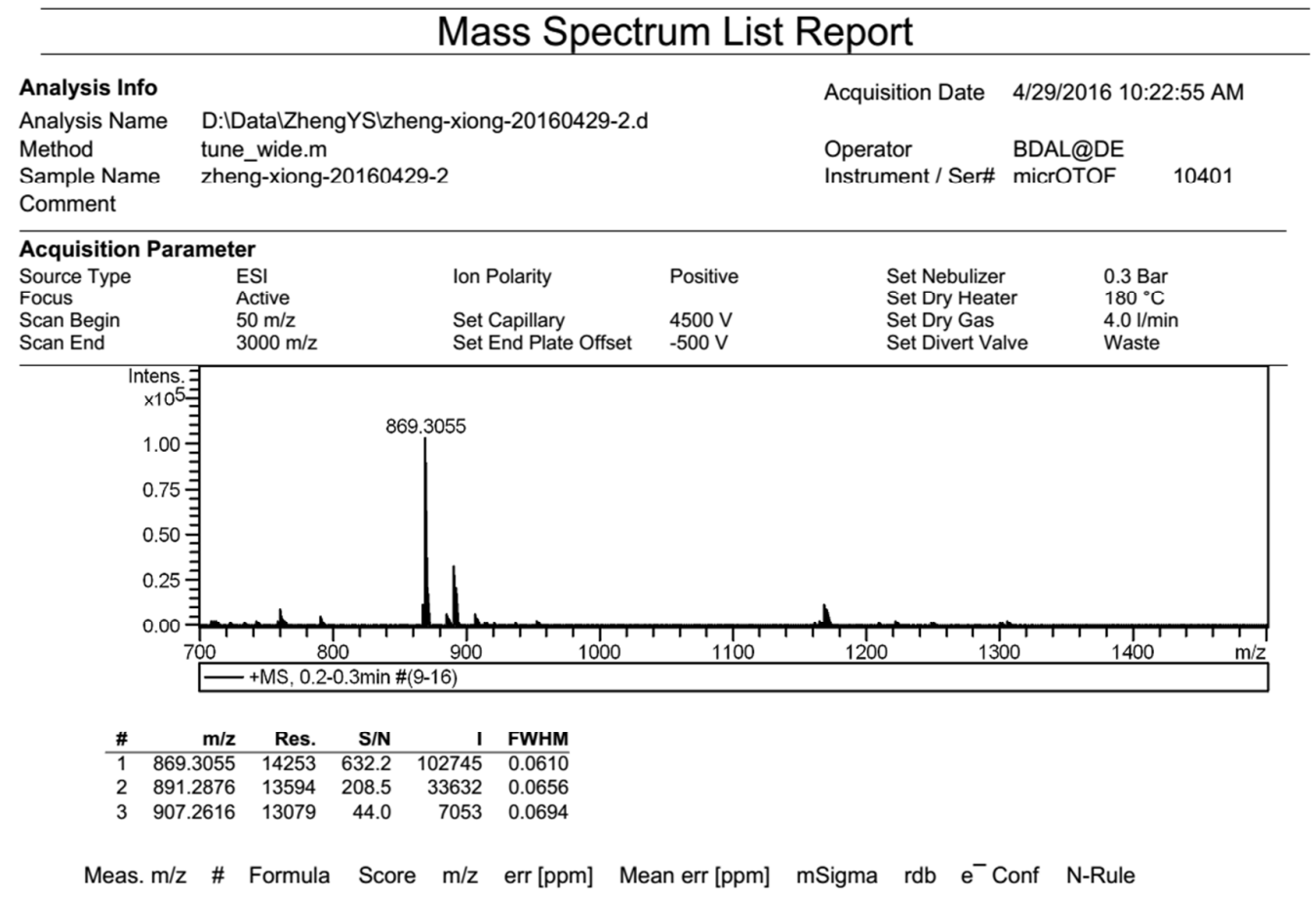

Fig. S20. HRMS spectrum of M-6. 


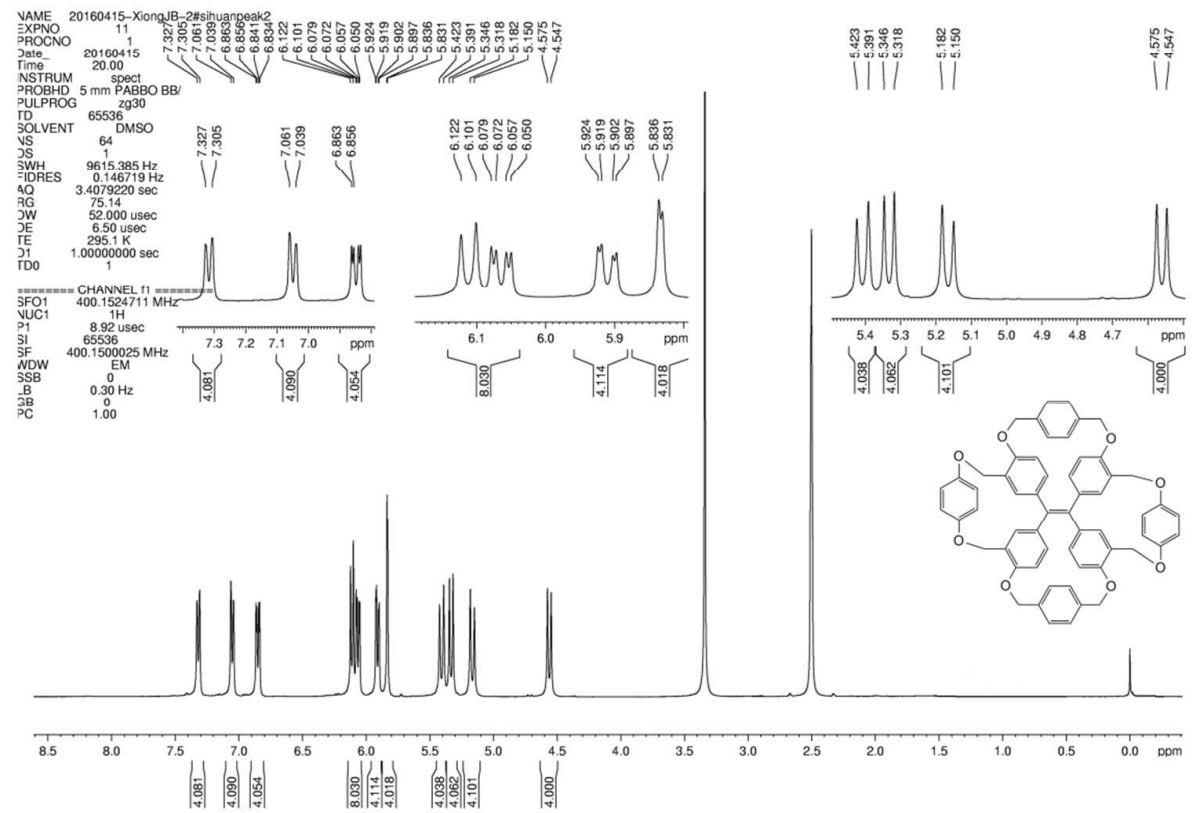

Fig. S21. ${ }^{1} \mathrm{H}$ NMR spectrum of P-6 in DMSO- $\mathrm{d}_{6}$.

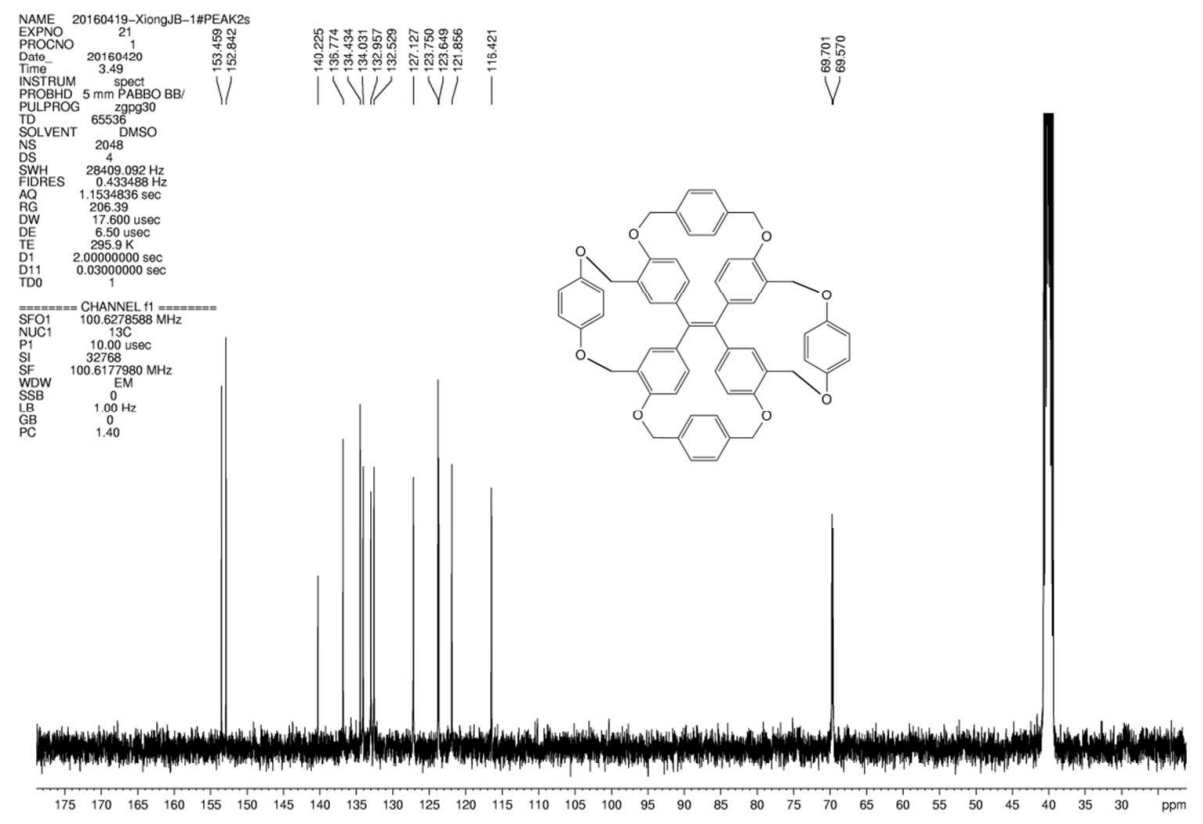

Fig. S22. ${ }^{13} \mathrm{C}$ NMR spectrum of P-6 in DMSO- $\mathrm{d}_{6}$. 


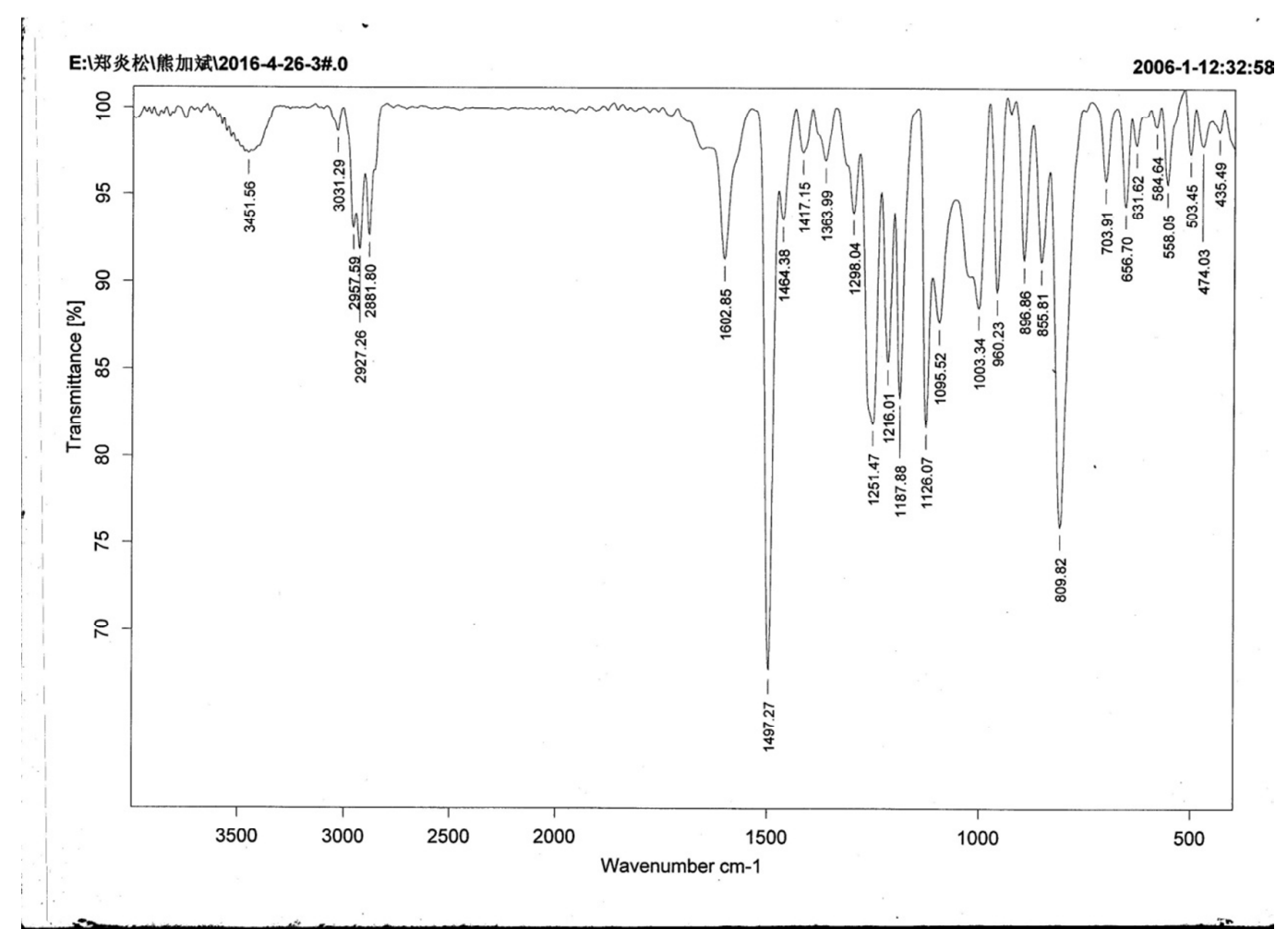

Fig. S23. IR spectrum of P-6. 


\section{Mass Spectrum List Report}

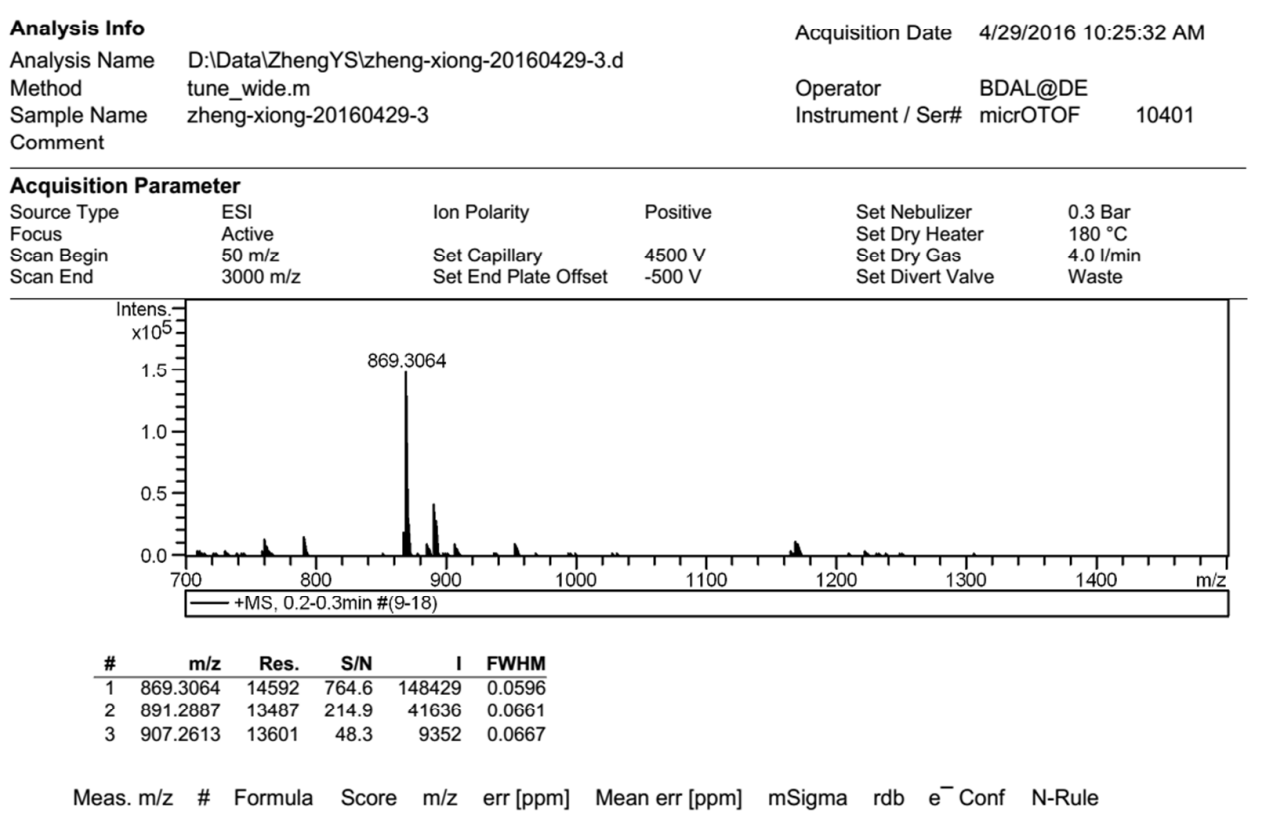

\begin{tabular}{llll}
\hline Bruker Compass DataAnalysis 4.0 & printed: & 4/29/2016 12:03:24 PM & Page 1 of 1
\end{tabular}

Fig. S24. HRMS spectrum of P-6. 


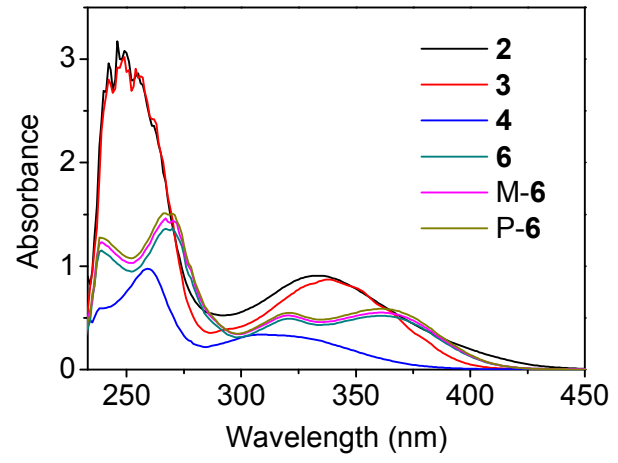

Fig. S25. UV-vis spectra of compounds 2, 3, 4, racemic-6, M-6, and P-6 in THF. [2] $=[3]=$ $[4]=[$ racemic-6 $]=[\mathrm{M}-6]=[\mathrm{P}-6]=5.0 \times 10^{-5} \mathrm{M}$.

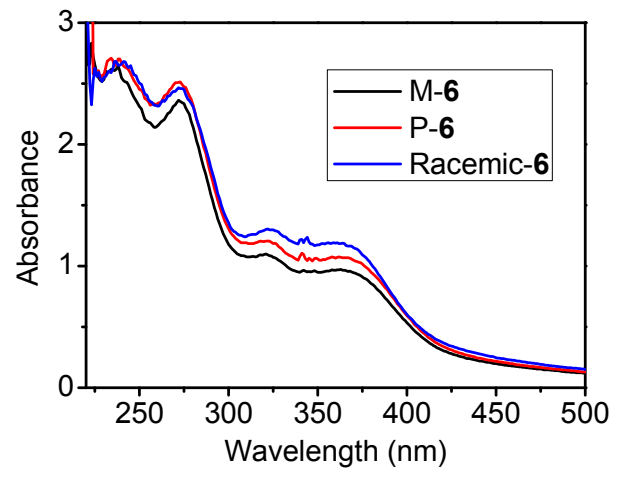

Fig. S26. UV-vis spectra of compounds M-6, P-6 and racemic-6 in 90:10 $\mathrm{H}_{2} \mathrm{O} / \mathrm{THF}$. [M-6] = $[\mathrm{P}-6]=[$ racemic-6 $]=5.0 \times 10^{-5} \mathrm{M}$.

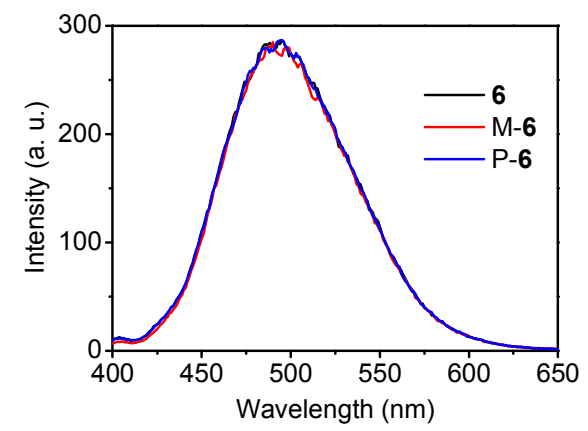

Fig. S27. Fluorescence spectra of racemic-6, M-6 and P-6 in THF at $5.0 \times 10^{-5}$ M. $\lambda_{\text {ex }}=376$ $\mathrm{nm}$, ex/em slit widths $=1.5 / 3 \mathrm{~nm}$. 


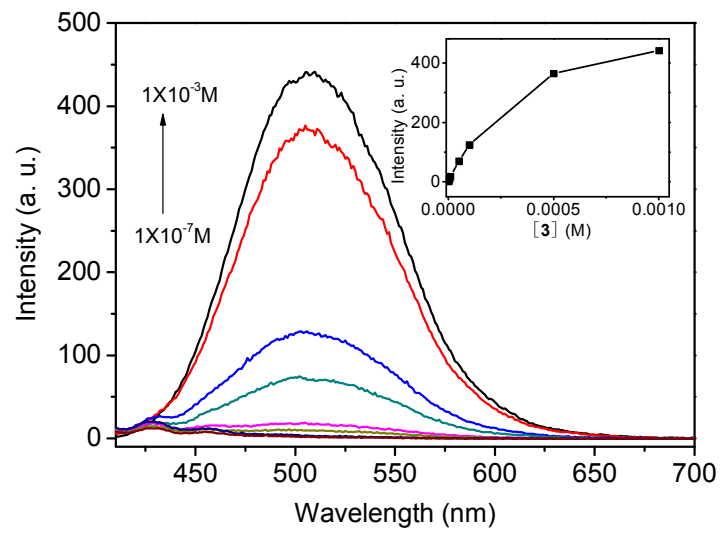

Fig. S28. Change of fluorescence spectrum of $\mathbf{3}$ in THF with concentration. Inset, curve of fluorescence intensity at $505 \mathrm{~nm}$ vs concentration of 3 in THF. $\lambda_{\mathrm{ex}}=402 \mathrm{~nm}$, ex/em slit widths $=3 / 3 \mathrm{~nm}$.

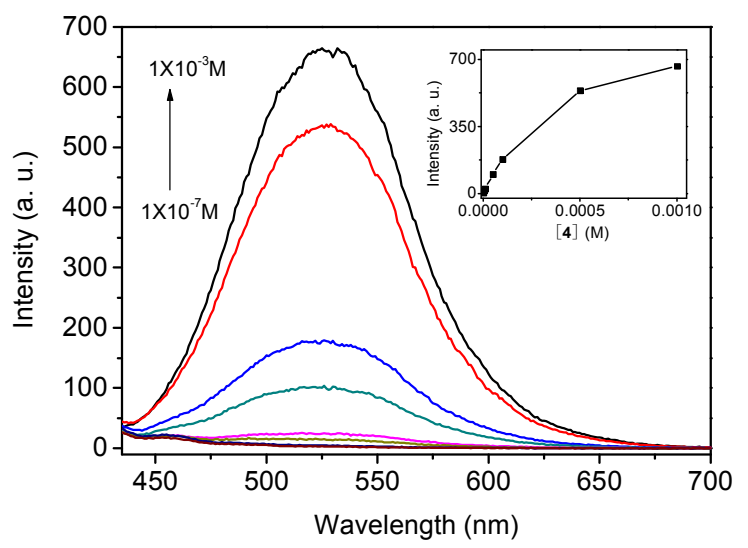

Fig. S29. Change of fluorescence spectrum of 4 in THF with concentration. Inset, curve of fluorescence intensity at $525 \mathrm{~nm}$ vs concentration of 4 in THF. $\lambda_{\text {ex }}=384 \mathrm{~nm}$, ex/em slit widths $=3 / 3 \mathrm{~nm}$. 


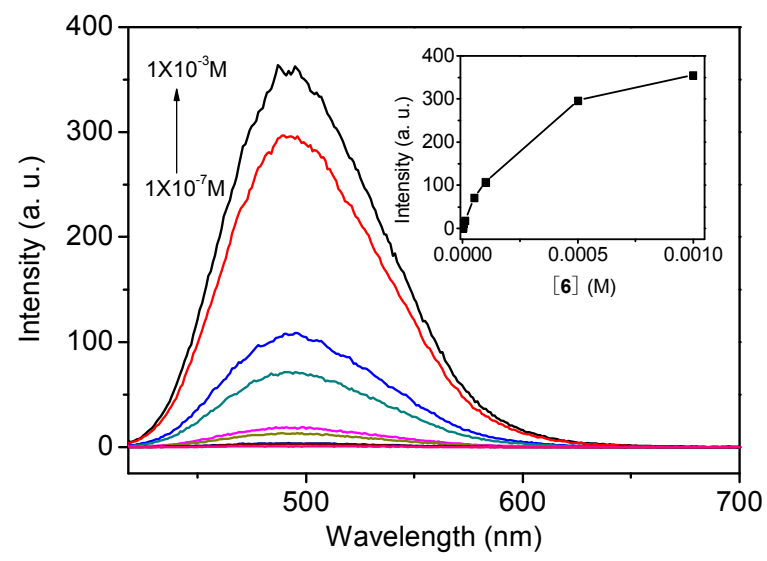

Fig. S30. Change of fluorescence spectrum of racemic-6 in THF with concentration. Inset, curve of fluorescence intensity at $490 \mathrm{~nm}$ vs concentration of racemic-6 in THF. $\lambda_{\text {ex }}=413 \mathrm{~nm}$, ex/em slit widths $=1.5 / 3 \mathrm{~nm}$.

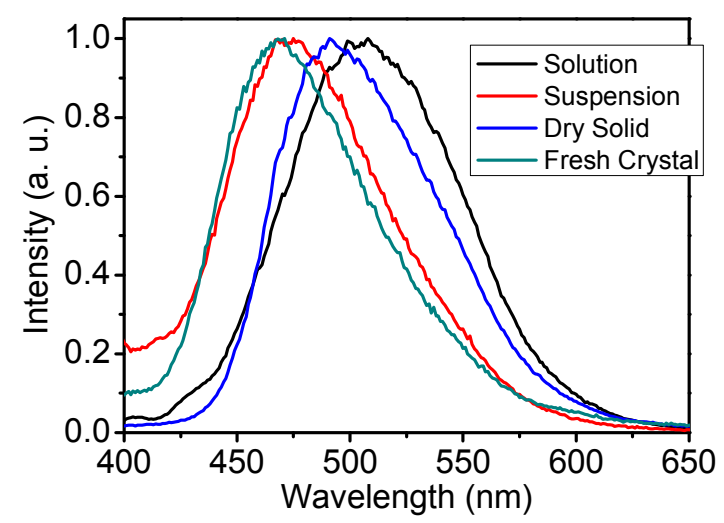

Fig. S31. Normalized fluorescence spectra of $\mathbf{3}$ in THF solution and in 95:5 $\mathrm{H}_{2} \mathrm{O} / \mathrm{THF}$ (V/V) suspension, in dry solid and in fresh crystals. $[3]=1.0 \times 10^{-4} \mathrm{M}$. 


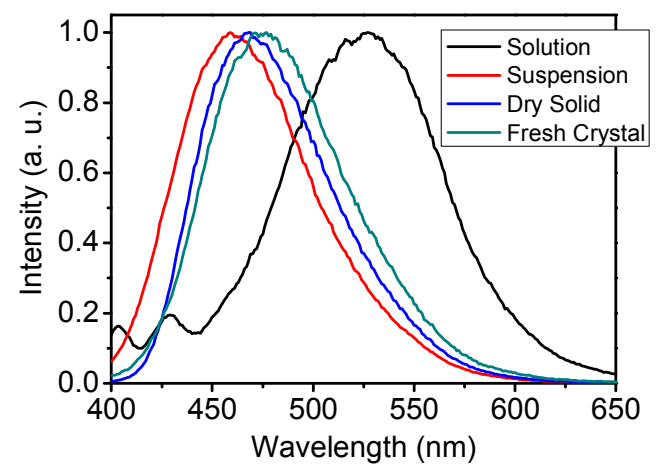

Fig. S32. Normalized fluorescence spectra of 4 in THF solution, in 95:5 $\mathrm{H}_{2} \mathrm{O} / \mathrm{THF}(\mathrm{V} / \mathrm{V})$ suspension, in dry solid and in fresh crystals. $[4]=1.0 \times 10^{-4} \mathrm{M}$.

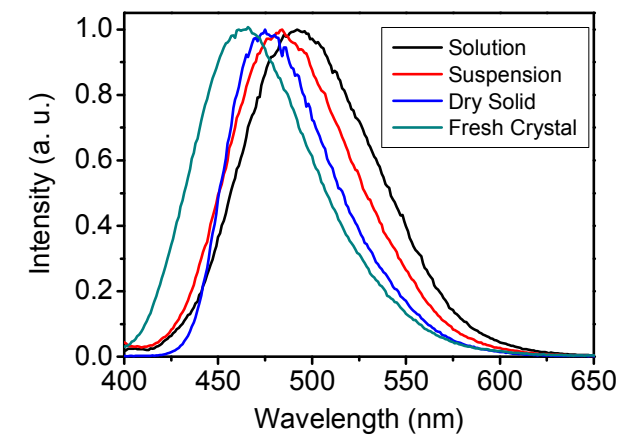

Fig. S33. Normalized fluorescence spectra of racemic-6 in THF solution and in 95:5 $\mathrm{H}_{2} \mathrm{O} / \mathrm{THF}(\mathrm{V} / \mathrm{V})$ suspension, in dry solid and in fresh crystals. [racemic-6] $=1.0 \times 10^{-4} \mathrm{M}$. 

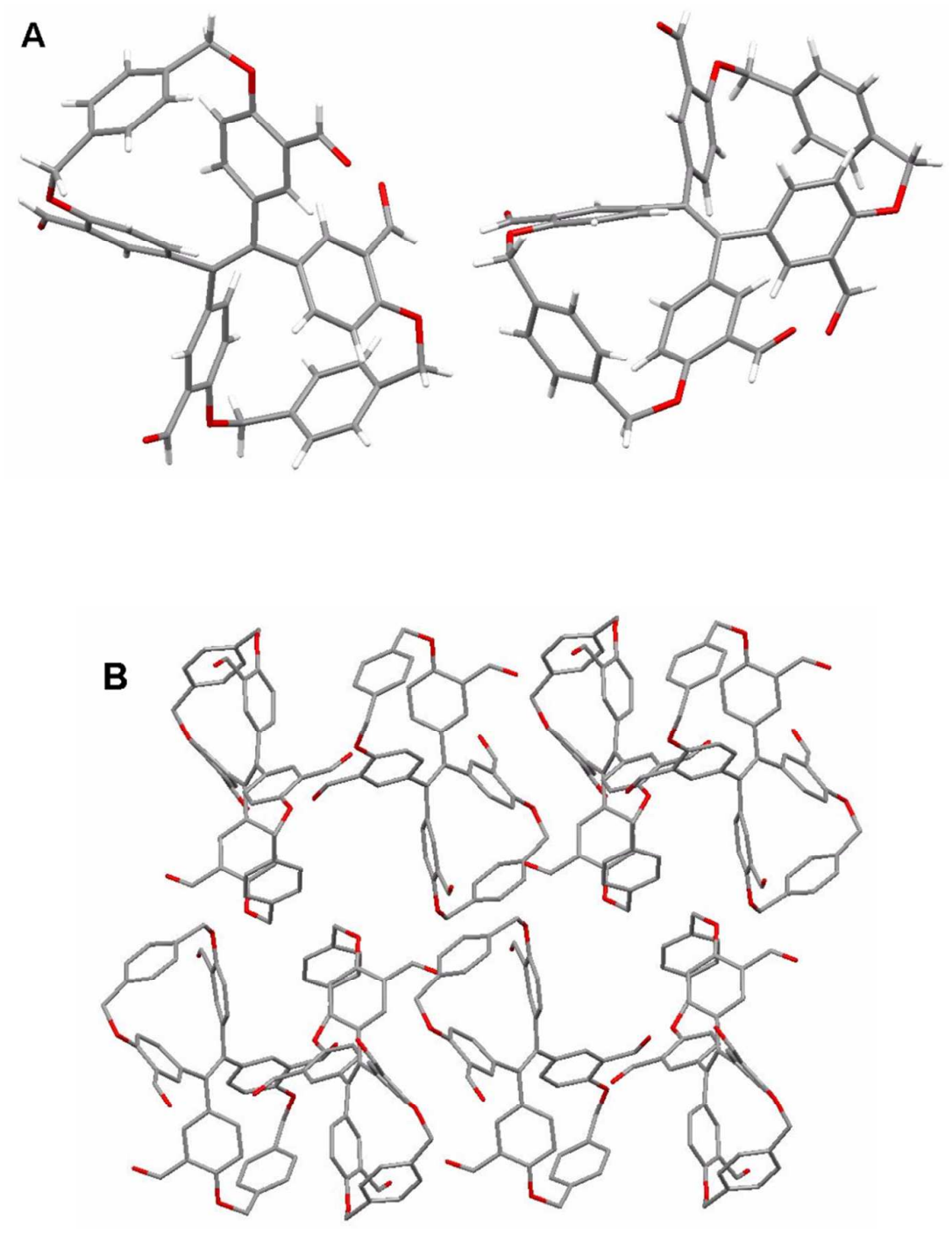

Fig. S34. Crystal structure (A) and packing with same helical chirality (B) of $\mathbf{3}$ in crystal state. The hydrogen in $\mathrm{B}$ and solvents in $\mathrm{A}-\mathrm{B}$ were removed for clarity. 


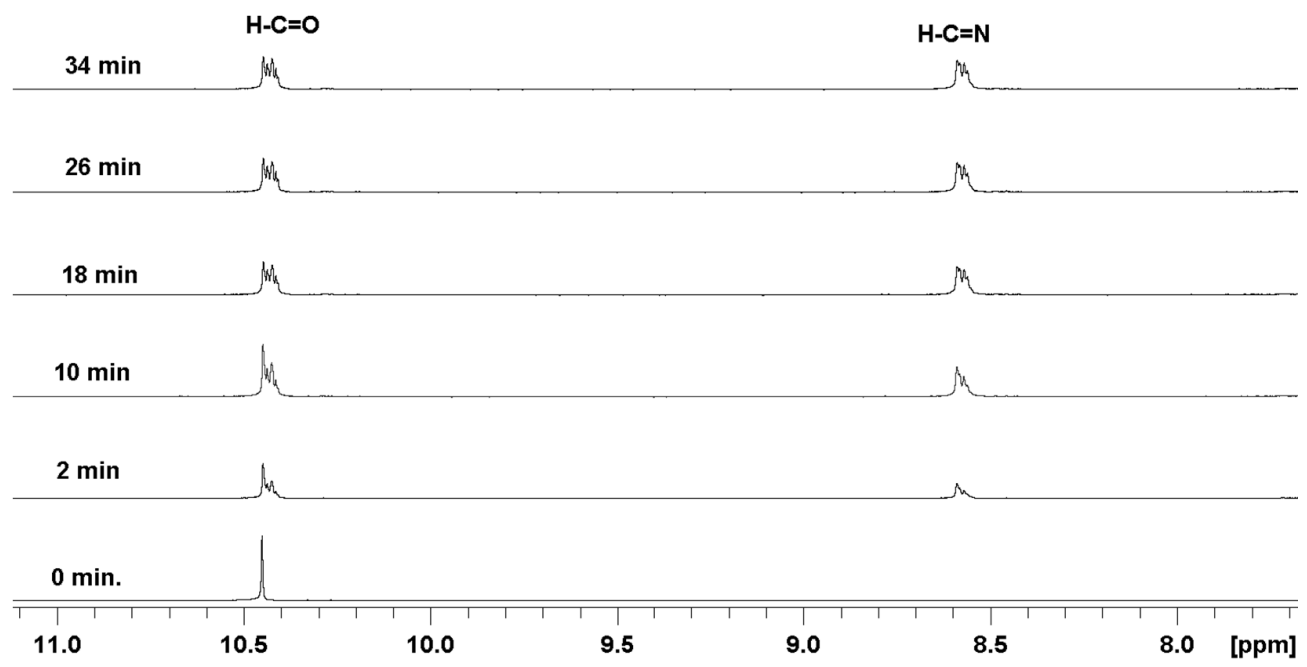

Fig. S35. Change in partial ${ }^{1} \mathrm{H}$ NMR spectra of the solution of enantiomers of $S-7, \mathbf{3}$, and HAc in $\mathrm{CDCl}_{3}$ with time at $30{ }^{\circ} \mathrm{C}$. $[3]=1 / 5[S-7]=1 / 10[\mathrm{HAc}]=5.0 \times 10^{-3} \mathrm{M}$. When the reaction solution was left to stand at $30{ }^{\circ} \mathrm{C}$ for $0 \mathrm{~min}, 2 \mathrm{~min}, 10 \mathrm{~min}, 18 \mathrm{~min}, 26 \mathrm{~min}$, and $34 \mathrm{~min}$, the percentage of the formed imine in original total aldehydes was $0 \%, 35 \%, 40 \%, 48 \%, 49 \%$, and $48.5 \%$, respectively. The dynamical equilibrium was reached in about $30 \mathrm{~min}$. 

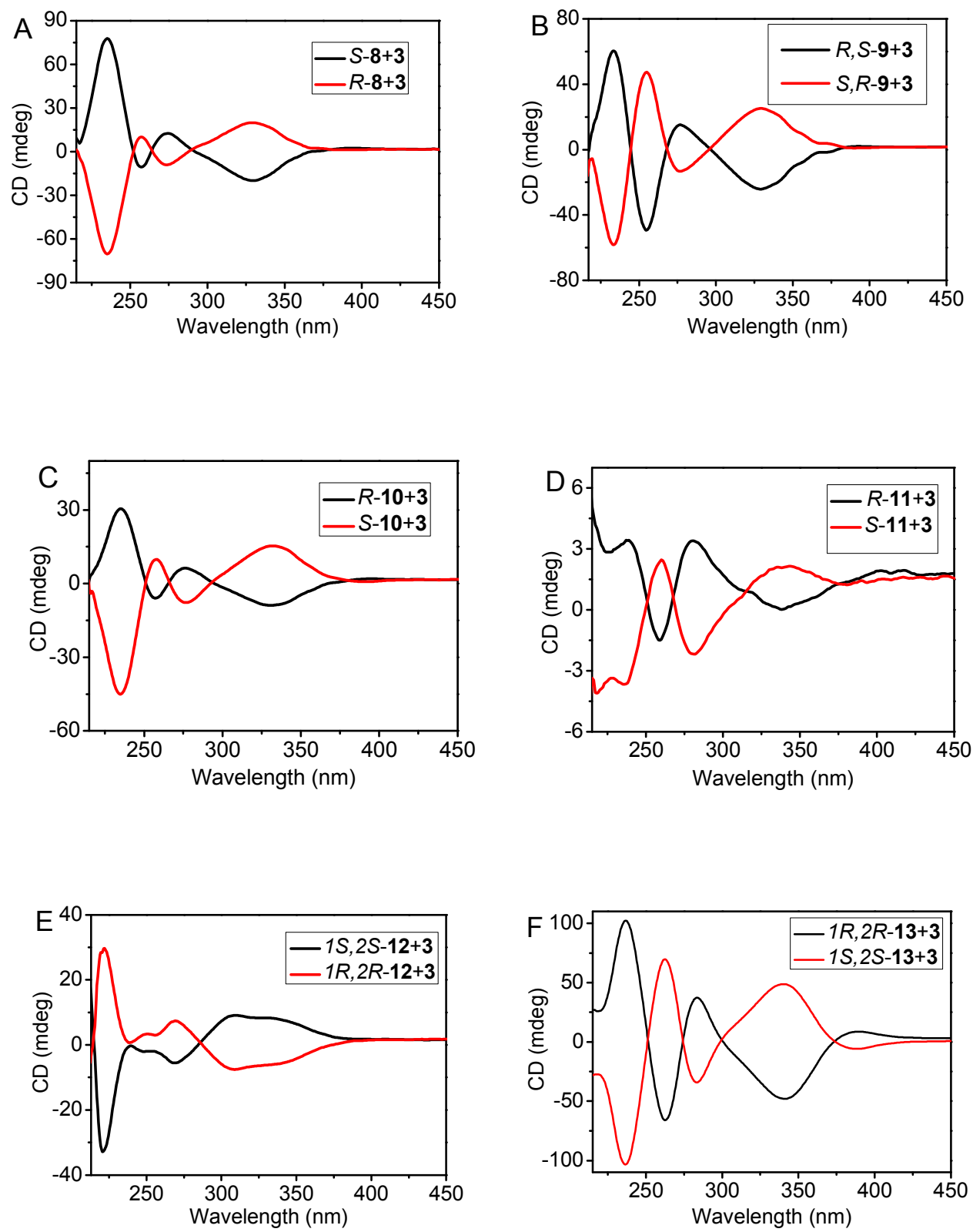

Fig. S36. CD spectra of the solution of enantiomer of chiral amine and acetic acid (HAc) with 3 in 1,2-dichloroethane. (A) 8; (B) 9; (C) 10; (D) 11; (E) 12; (F) 13. [3] =1/10[amine] = $1 / 20[\mathrm{HAc}]=2.0 \times 10^{-4} \mathrm{M}$, the solution was left to stand for $60 \mathrm{~min}$ at room temperature before measurement. 

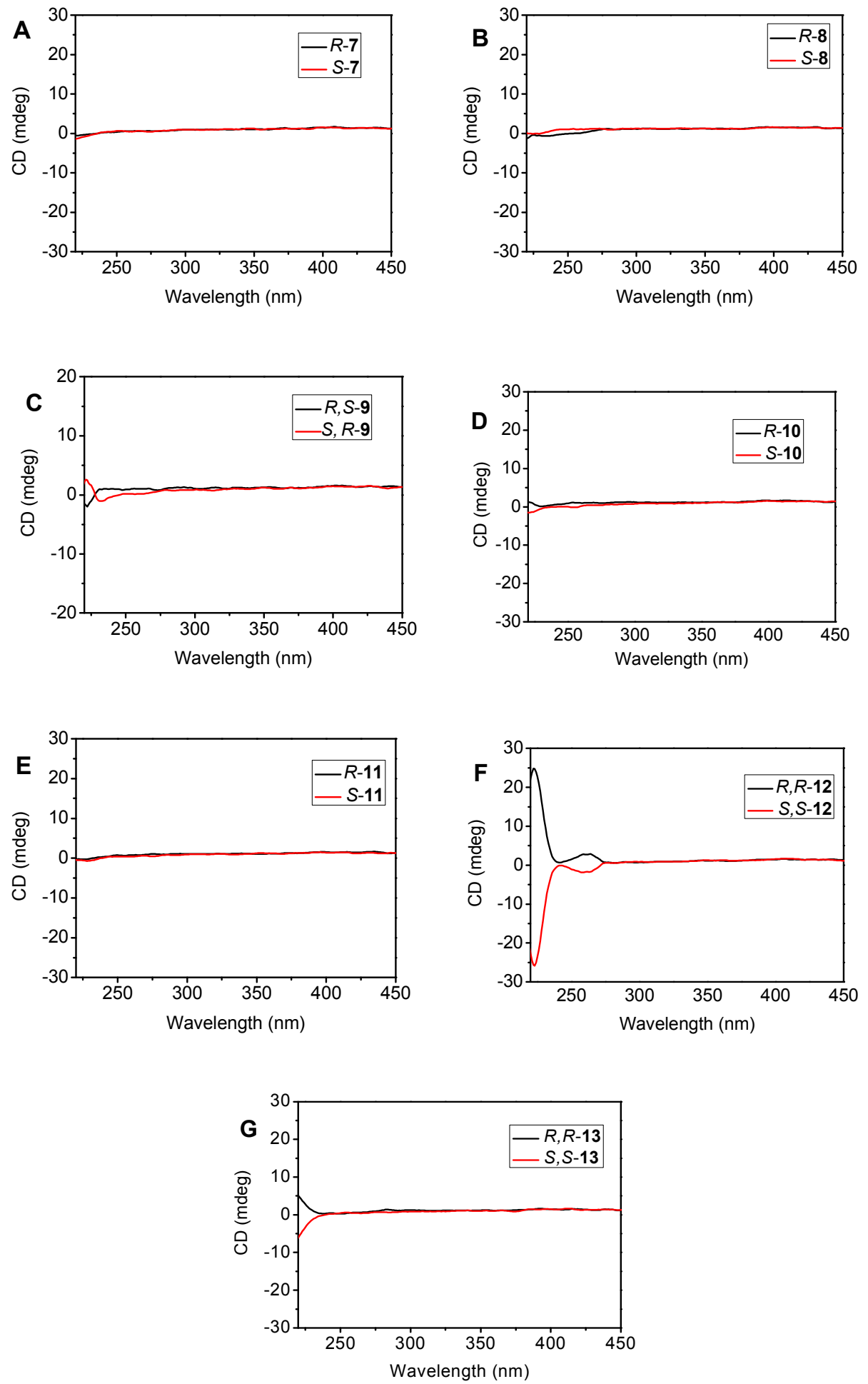

Fig. S37. CD spectra of the solution of enantiomers of chiral amine and HAc in 1,2dichloroethane. (A) 7; (B) 8; (C) 9; (D) 10; (E) 11; (F) 12; (G) 13. [amine] $=2.0 \times 10^{-3} \mathrm{M}$, the solution was left to stand for $60 \mathrm{~min}$ at room temperature before measurement. 

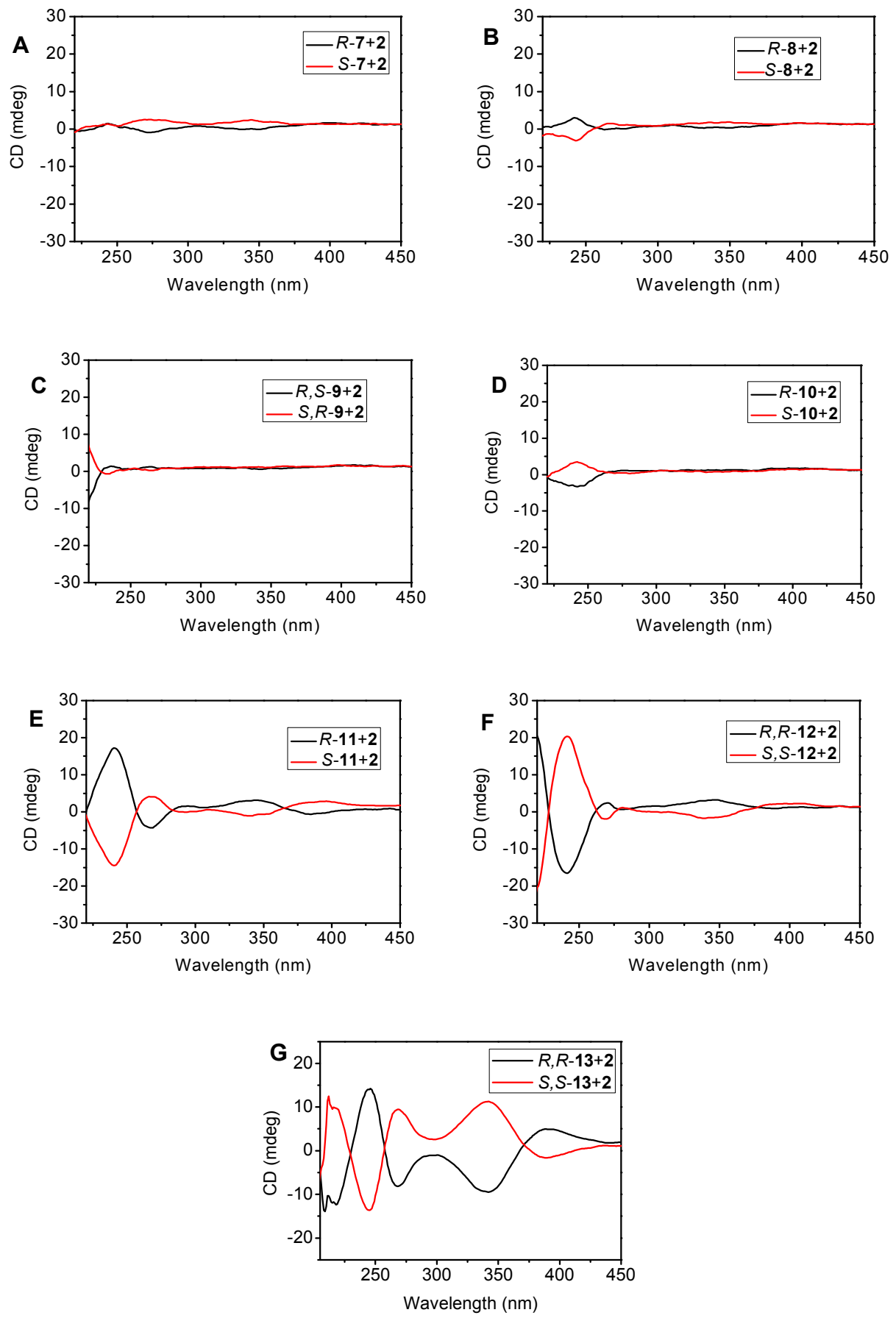

Fig. S38. CD spectra of the solution of enantiomer of chiral amine, HAc, and 2 in 1,2dichloroethane. (A) 7; (B) 8; (C) 9; (D) 10; (E) 11; (F) 12; (G) 13. [2] = 1/10[amine] = $1 / 20[\mathrm{HAc}]=2.0 \times 10^{-4} \mathrm{M}$, the solution was left to stand for $60 \mathrm{~min}$ at room temperature before measurement. 


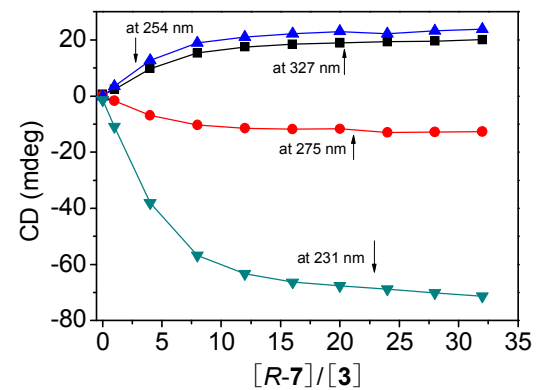

Fig. S39 . Change in CD spectra of the solution of $R-7,3$, and HAc in 1,2-dichloroethane with molar ratios of $R-7$ vs 3. [3] $=1 / 20[\mathrm{HAc}]=2.0 \times 10^{-4} \mathrm{M}$, the solution was left to stand for 60 min at room temperature before measurement.

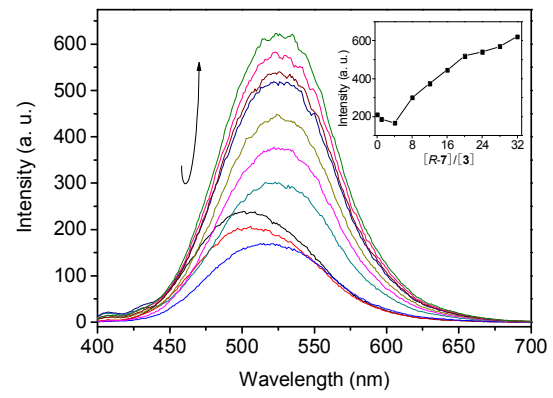

Fig. S40 . Change in fluorescence spectra of the solution of $R-7,3$, and HAc in 1,2dichloroethane with $R-7$ vs 3. [3] $=1 / 20[\mathrm{HAc}]=2.0 \times 10^{-4} \mathrm{M}$, the solution was left to stand for $60 \mathrm{~min}$ at room temperature before measurement. Inset, curves of fluorescence intensity at $526 \mathrm{~nm}$ vs molar ratios of $[R-7] /[3] . \lambda_{\mathrm{ex}}=367 \mathrm{~nm}$, ex/em slit widths $=3 / 5 \mathrm{~nm}$.

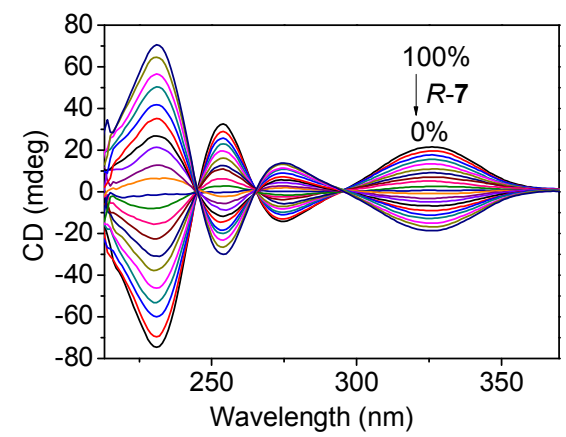

Fig. S41. Change in CD spectra of the solution of enantiomers of 7, 3, and HAc in 1,2dichloroethane with ee $\%$ of $R-7$. [3] $=1 / 10[7]=1 / 20[\mathrm{HAc}]=2.0 \times 10^{-4} \mathrm{M}$. 

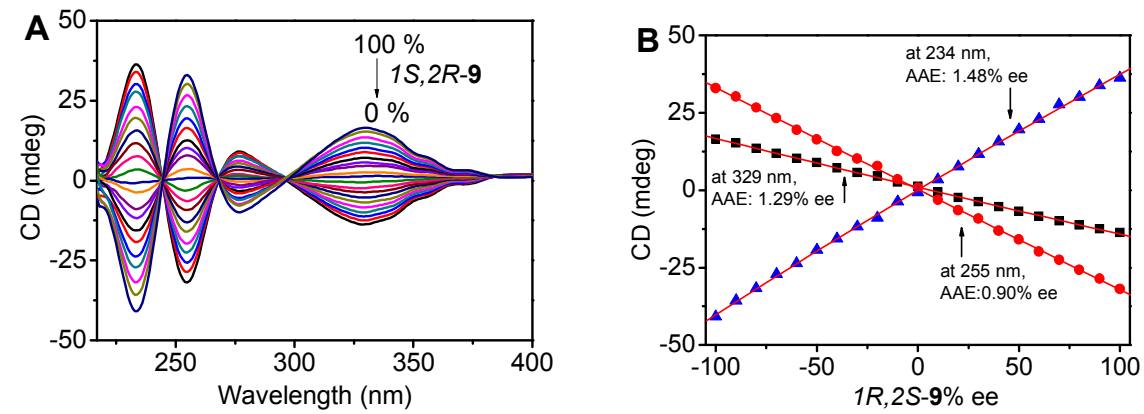

Fig. S42. (A). Change in CD spectra of the solution of enantiomers of 2-amino-1,2diphenylethanol 9, 3, and HAc in 1,2-dichloroethane with ee\% of $R-\mathbf{9}$. (B) Change in CD intensity with ee\% of $R-\mathbf{9}$, the red line is the linear fitting result. AAE, absolute average error. $[3]=1 / 10[9]=1 / 20[\mathrm{HAc}]=2.0 \times 10^{-4} \mathrm{M}$, the solution was left to stand for $60 \mathrm{~min}$ at room temperature before measurement.
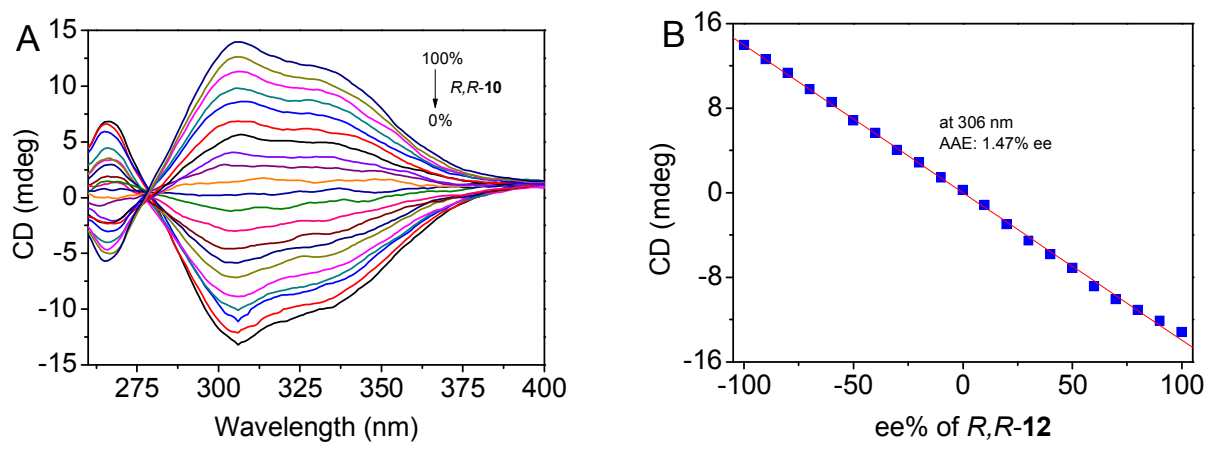

Fig. S43. (A). Change in CD spectra of the solution of enantiomers of 1,2diphenylethanediamne 12, 3, and HAc in acetonitrile with ee\% of $R, R-12$. (B) Change in CD intensity with ee $\%$ of $R, R-\mathbf{1 2}$, the red line is the linear fitting result. AAE, absolute average error. $[\mathbf{3}]=1 / 10[\mathbf{1 2}]=1 / 20[\mathrm{HAc}]=2.0 \times 10^{-4} \mathrm{M}$, the solution was left to stand for $60 \mathrm{~min}$ at room temperature before measurement. 

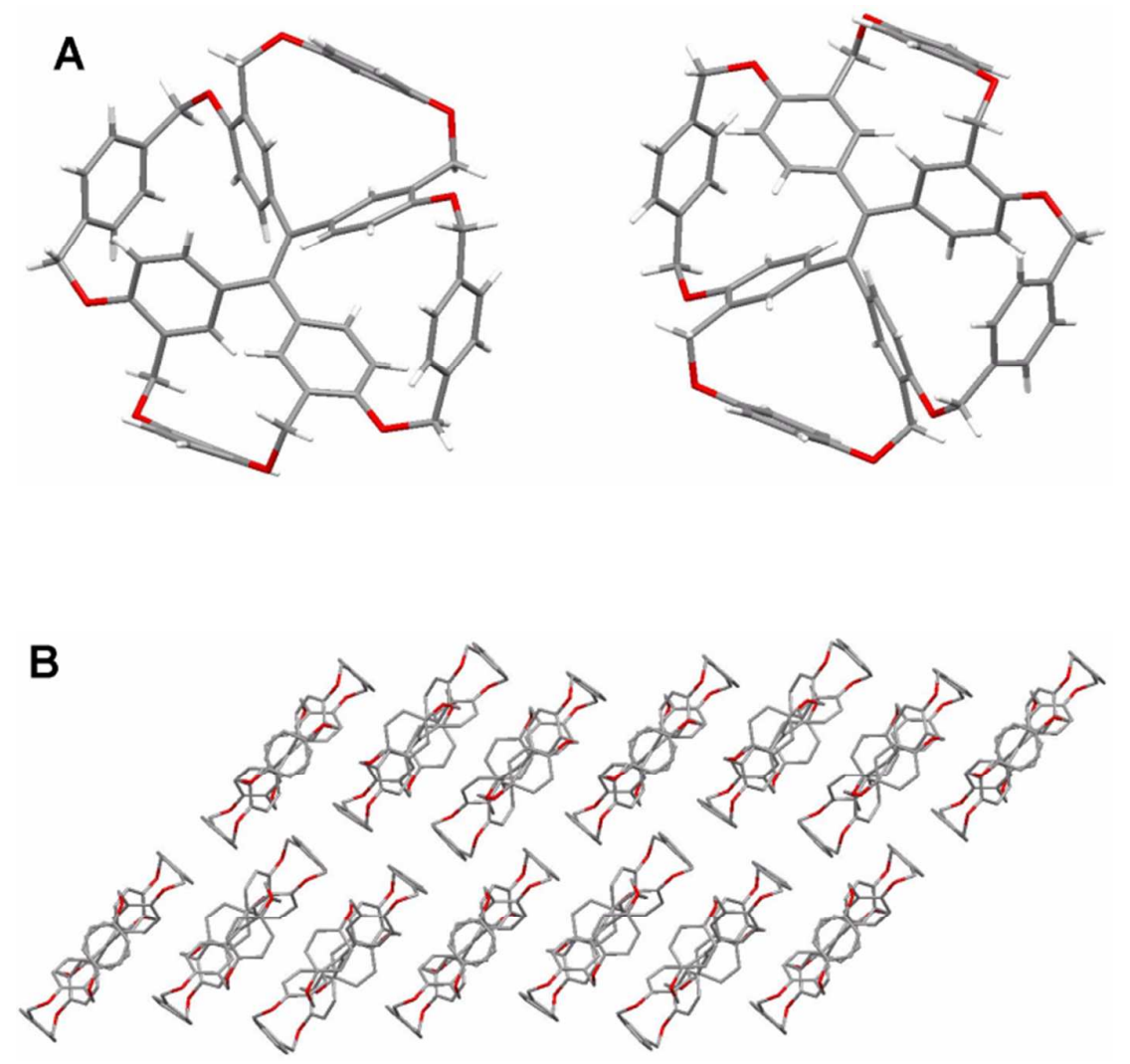

Fig. S44. Crystal structure (A) and packing with same helical chirality (B) of racemic-6 in crystal state. The hydrogen in B and solvents in A-B were removed for clarity. 

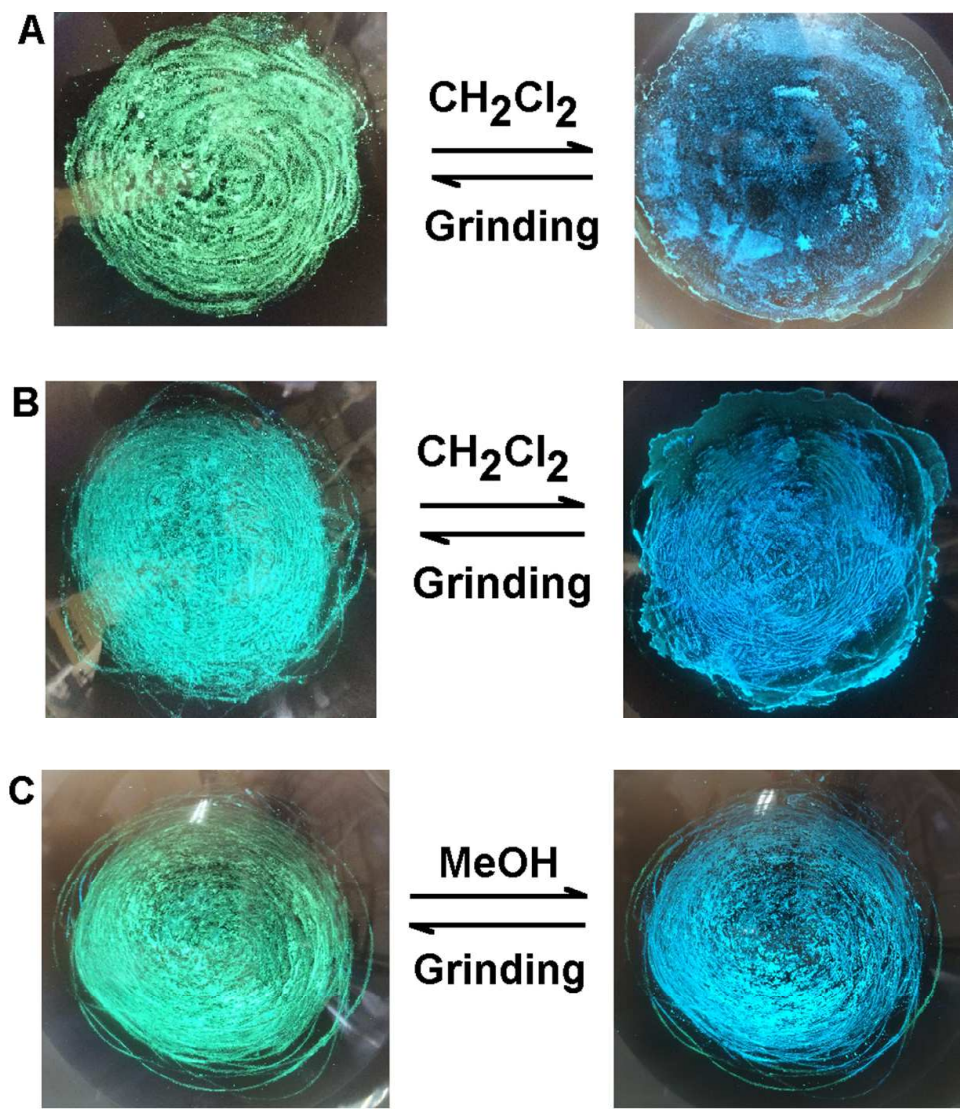

Fig. S45. Photos of powders of 3 (A), 4 (B) and 6 (C) under a portable UV lamp after ground and treated by methanol or dichloromethane. 